\title{
Profiling Human CMV-specific T cell responses reveals novel immunogenic ORFs
}

1 Rekha Dhanwani ${ }^{1 \dagger}$, Sandeep Kumar Dhanda ${ }^{1 \#}$, John Pham ${ }^{1}$, Gregory P. Williams ${ }^{1}$,

2 John Sidney ${ }^{1}$, Alba Grifoni ${ }^{1}$, Gaelle Picarda ${ }^{1,3}$, Cecilia S. Lindestam Arlehamn ${ }^{1}$,

3 Alessandro Sette ${ }^{1,2, *}$, Chris A Benedict $1,3, *$

4

$5 \quad{ }^{1}$ Center for Infectious Disease and Vaccine Research, La Jolla Institute for Immunology,

6 La Jolla, CA 92037, USA

$7 \quad{ }^{2}$ Department of Medicine, University of California San Diego, La Jolla, CA 92093, USA

$8{ }^{3}$ Center for Autoimmunity and Inflammation, La Jolla Institute for Immunology, La Jolla,

9 CA 92037, USA

10 † Present Address: Division of Extramural Activities, National Institute of Allergy and

11 Infectious Diseases, National Institute of Health, Rockville, MD 20852, USA

12 \# Present Address: St. Jude Children's Research Hospital, Arlington, VA 22203

13

$14{ }^{*}$ Corresponding authors

15 Alessandro Sette

16 Email: alex@lji.org

18 Chris A. Benedict

19 Email: benedict@lii.org 


\section{Abstract}

23 Despite the prevalence and medical significance of human cytomegalovirus (HCMV)

24 infections, a systematic analysis of the targets of $\mathrm{T}$ cell recognition in humans that spans

25 the entire genome and includes recently described potential novel ORFs is not available.

26 Here, we screened a library of epitopes predicted to bind HLA class II that spans over

27350 different HCMV ORFs and includes $\sim 150$ previously described and $\sim 200$ recently

28 described potential novel ORFs using an ex vivo IFN $\gamma$ fluorospot assay. We identified 235

29 unique HCMV specific epitopes derived from 100 ORFs, some previously described as

30 immunodominant and others that were not previously described to be immunogenic. Of

31 those, 41 belong to the set of recently reported novel ORFs, thus providing evidence that

32 at least some of these are actually expressed in vivo in humans. These data reveal that

33 the breadth of the human T cell response to HCMV is much greater than previously

34 thought. The ORFs and epitopes identified will help elucidate how $\mathrm{T}$ cell immunity relates

35 to HCMV pathogenesis and instruct ongoing HCMV vaccine research.

\section{Importance}

38 To understand the crucial role of adaptive immunity in controlling cytomegalovirus

39 infection and disease, we systematically analyzed the CMV 'ORFeome' to identify new

40 CMV epitopes targeted primarily by CD4 T cells in humans. Our study identified $>200$

41 new $\mathrm{T}$ cell epitopes derived from both canonical and novel ORFs, highlighting the

42 substantial breadth of anti-CMV T cell response and providing new targets for vaccine 43 design. 


\section{Introduction}

Human cytomegalovirus (HCMV, HHV-5) is a $\beta$-herpesvirus that infects the

47 majority of the world's population. Infection in healthy individuals is characterized by a primary asymptomatic phase followed by the establishment of lifelong persistence/latency in several cell types $(1,2)$. HCMV's $236 \mathrm{kbp}$ double stranded DNA genome facilitates its persistence and reactivation when immunity is compromised, with both viral and cellular

51 proteins controlling viral gene expression and regulating the dynamic and reversible

52 latent-lytic cycle that develops over a lifelong infection (3, 4). Although largely persistent,

53 its reactivation in immunocompromised populations, such as transplant recipients and

54 AIDS patients, causes severe disease outcomes (5-11). Congenital infection in the

55 developing fetus is also the leading infectious cause of birth defects (12-18). Moreover,

56 the available antiviral drug therapies are insufficient and often toxic in young children (19-

57 22). Consequently, HCMV is recognized as a major public health problem and

58 development of a vaccine that prevents or at least mitigates virus-induced disease is a 59 top priority (23-25) .

Although both humoral and cell mediated immune responses protect against

61 HCMV infection, a considerable effort has been made towards identifying HCMV targets

62 of CTL responses due to their pivotal role in controlling HCMV disease in

63 immunocompromised individuals (26-29). However, HCMV targets of CD4+ T helper

64 cells, which amplify CTL and antibody responses or may mediate direct antiviral activity

65 themselves, remain to be explored in detail. In order to develop a successful HCMV 66 vaccine, it is imperative to assess the large number of candidate viral proteins for their 67 potential to induce robust CD4+ T cell responses. 
Previous work from Sylwester et al. extensively characterized the canonical HCMV

69 proteins that are targeted by CD4+ and CD8+ T cell responses (30), and work by many

70 other groups have identified immunodominant epitopes derived from these that include

71 the 65kDA phosphoprotein (UL83/pp65), immediate early protein 1 (UL123), tegument

72 protein pp150 (UL32), envelope glycoprotein B (UL55), viral transcription factor IE2

73 (UL122), and major capsid protein (UL86) (31-38). However, a comprehensive analysis

74 of HCMV epitope-specific T cell responses has been challenging, mainly due to the large

75 size of virus and the evolving impact that persistent infection has on the memory pool.

76 Stern-Ginossar et al. recently reported all the HCMV RNAs found to be associated with

77 ribosomes in infected fibroblasts, increasing the potential number of ORFs the virus may

78 encode by $\sim 3$ fold (39). Here, we designed a comprehensive screening approach to

79 assess potential $T$ cell responses against 563 of these ORFs, which included both

80 previously reported and potentially novel HCMV proteins. 2593 15-mer peptides were

81 predicted using computational algorithms, and a high throughput screen was performed

82 using an IFN $\gamma$ fluorospot assay to identify epitopes targeted by both CD8+ and CD4+ T

83 cells in healthy HCMV-infected adults. This 'whole ORFeome' approach resulted in the

84 identification of more than 200 new CD4+ and CD8+ T cell epitopes. 


\section{Results}

\section{Targets of HCMV T cell reactivity}

To define the epitopes targeted by HCMV-specific T cell responses in healthy

90 adults, we screened PBMCs of 19 subjects, 10 males and 9 females, recruited from the

91 San Diego blood bank (SDBB). The HCMV seropositivity of all the subjects was confirmed

92 by IgG ELISA (Fig. S1A). We tested a total of 2593 15-mer HCMV peptides covering a

93 total of 563 ORFs (39). Removing the predicted ORFs that were located entirely within

94 longer ORFs resulted in a set of 359 completely unique ORFs. This set consists of

95 approximately 150 "canonical" ORFs, with an additional 200 identified by ribosomal RNA

96 profiling (39). These 15-mer peptides corresponded to epitopes likely to be dominant

97 based on a bioinformatic method that predicts promiscuous binding to HLA class II

98 molecules (40). Each ORF analyzed contained a minimum of 2 predicted epitopes, with

99 the exception of very small ORFs of less than 15-20 amino acid residues, in which case

100 at least one peptide was synthetized. The 2593 peptides were arranged in 89 pools of

10128 to 30 15-mers. The PBMC reactivity of each of the 89 pools was assayed directly ex

102 vivo using an IFN- $\gamma$ Fluorospot assay. After identifying the pools that resulted in IFN- $\gamma$

103 production in $\mathrm{HCMV}+$ individuals, the top 10 most reactive pools (that, on average,

104 accounted for more than $90 \%$ of the reactivity observed within each subject) were then

105 deconvoluted to identify the specific epitopes (Fig. S2). Representative results from the

106 initial screening and the deconvolution of a pool in a representative subject are shown in

107 Fig. 1A-B. In conclusion, the results shown here indicate that human $\mathrm{T}$ cell responses to

108 HCMV recognize a wide breadth of different epitope specificities. 


\section{Characterization of CMV epitope-specific immune responses}

111 The deconvolution of the top 10 pools from each subject identified widespread

112 reactivity directed against 235 unique epitopes (Fig. S3 and Table 1). Interestingly,

113 females tended to show both a higher frequency and magnitude of epitope-specific

114 responses when compared to males, although this did not reach statistical significance

115 (Fig. S4). On average, each subject recognized 25 epitopes (Fig. 2A) and all subjects

116 recognized at least 2 (range 2-57, Fig. 2B). Specifically, 6 out of 19 donors recognized

$11721-30$ epitopes. A quarter of the epitopes (58 of the 235 recognized) were recognized by

118 three or more subjects (Fig. 2C), and these accounted for $76 \%$ of the total T cell response

119 (Fig. 2D).

We further characterized the phenotype of the $\mathrm{T}$ cell responses directed against

121 these 58 dominant epitopes by intracellular IFN- $\gamma$ staining (representative results shown

122 in Fig. 3A, with the flow cytometry gating strategy shown in Fig. S5A). In the majority of

123 tested subjects, the responding $\mathrm{T}$ cells were CD4+. More specifically, $68 \%$ of all

124 responding T cells were CD4+ and $13 \%$ contained both IFN- $\gamma+$ CD4+ and CD8+. In 18\%

125 of the cases, only CD8+ T cells responded to these 58 epitopes (Fig. 3B). Similarly, if the 126 magnitude of the response was considered, $70 \%$ of the IFN- $\gamma$ response was attributable

127 to CD4+ T cells and only $30 \%$ emanated from CD8+ T cells (Fig. $3 \mathbf{C}$ ). The fact that the 128 responses were dominated by CD4+ T cells is consistent with the fact that the peptides

129 tested were originally selected based on their predicted likelihood to bind HLA class II 130 alleles. In turn, the occasional identification of epitope-specific CD8+ T cell responses in 131 many cases likely reflects class I epitopes nested within the 15-mer epitopes tested in the 
132 screen. Overall, these results indicate that, as expected, the screening strategy employed

133 mostly identifies targets of CD4+ T cell reactivity.

\section{Analysis of the ORF of origin of the identified epitopes}

The 235 epitopes identified mapped to a total of 100 of the 359 unique ORFs

136 screened. Of those, 28 ORFs contained $>3$ immunogenic peptides and 18 ORFs were

137 recognized in $15 \%$ or more of the donors (Fig. 4). Notably, the previously well138 characterized immunodominant ORFs such as envelope glycoprotein B (UL55), IE1 139 (UL123), tegument protein pp65 (UL83), major capsid protein UL86, IE2 (UL122), and 140 pp150 (UL32) were amongst those associated with more than three immunogenic 141 peptides.

142 To address the novelty of our findings, we compared our results with ORFs that 143 have already been reported and curated in the Immune Epitope Database (IEDB 144 http://www.iedb.org) (41), as a source of defined epitopes. Specifically, a query of the 145 IEDB in October 2020 for previously characterized targets of $\mathrm{T}$ cell responses tested in 146 at least 19 donors and with a minimum response frequency of $15 \%$ revealed 7 ORFs that 147 match the conditions of our screening results: UL83/pp65 (ORFL205C), UL123/IE1 148 (ORFL264C), UL122/IE2 (ORFL265C), UL55/gB (ORFL145C), UL32/pp150 (ORFL92C), 149 UL40 (ORFL105C) and UL98 (ORFL229W) (Fig. 4).

The same query revealed three additional ORFs that were not identified in our

151 screen. These ORFs were associated with a limited number of literature-reported and

152 IEDB curated epitopes: UL75/gH (ORFL184C; 1 epitope), UL44/DNA-pol 153 (ORFL112C.iORF1; 3 epitopes) and UL138 (ORFL313C; 1 epitope). Importantly, our 
154 screen identified 93 ORFs that were not previously described as targets of $\mathrm{T}$ cell 155 responses (Fig. 5).

$156 \quad$ Notably, 52 of these 93 ORFs were already described in the 'canonical HCMV' 157 annotated genome, but not all have been described as targets of human T cell responses.

158 Even more strikingly, 41 of these 93 ORFs corresponded to those viral mRNAs only 159 identified by recent ribosomal profiling studies (39), providing evidence that they are 160 translated in HCMV infected cells. These results indicate that our approach successfully 161 re-identified known ORFs as targets of $\mathrm{T}$ cell responses, and perhaps most importantly, 162 greatly expanded the repertoire of canonical and 'novel' ORFs recognized by $\mathrm{T}$ cells in 163 healthy adults.

164 Novel identified epitope pools elicit antigen specific CD4+ T cell responses. Lastly, we wanted to explore whether the epitopes identified in the presented study 166 could, alone or in combination with previously described epitopes, be utilized to generate 167 epitope "MegaPools" (MP) (42-46) to allow detection of CMV-specific CD4 T cell 168 responses. Accordingly, we generated a 'P235' MP encompassing the 235 CMV epitopes 169 identified in the present study. As a comparison, we considered the commercially 170 available CMV peptide pool (Mabtech, catalog 3619-1) encompassing a total of 42 CD4

171 and CD8 epitopes. Additionally, we synthetized a MP of known class II epitopes curated 172 in the IEDB database, encompassing a total of 187 CD4 epitopes (IEDB-II, Table 2).

173 These MPs were tested with PBMC from a new cohort of 20 individuals (6 males 174 and 14 females), which included both HCMV seropositive and seronegative donors (10 $175 \mathrm{CMV}^{+}$and $10 \mathrm{CMV}^{-}$, Fig. S1B for IgG ELISA CMV confirmation). None of the PBMC from 176 these subjects were used in the original epitope mapping experiments. PBMCs were 
177 stimulated with the Mabtech, P235, IEDB-II, or a combination of both P235/ IEDB-II MPs.

178 CD4+ T cell responses were measured as percentage of activation-induced marker assay

179 positive (OX40+ CD137+) CD4+ T cells and results are displayed in Fig. 6 (flow cytometry 180 gating strategy shown in Fig. S5B).

All HCMV MPs tested were associated with significantly higher CD4 AIM

182 responses in $\mathrm{HCMV}+$ individuals compared to HCMV- subjects as shown in Fig. 5

183 (statistical differences detailed in figure legend). When comparing AIM responses

184 between the HCMV pools, the P235, IEDB-II and P235/IEDB-II MPs were associated with

185 significantly higher HCMV-specific CD4 responses compared to the Mabtech pool

186 (geometric mean $0.15 \%$ vs $0.25 \%$ CD4 AIM+, $p=0.01$; and $0.15 \%$ vs $0.36 \%, p=0.004$, 187 and $0.15 \%$ vs $0.46 \%$ CD4 AIM+, $p=0.004$, respectively by Wilcoxon test). This was 188 expected, as the Mabtech pool contains fewer epitopes which are also mainly CD8 T cell 189 specific. Additionally, the combination of the P235 and IEDB-II MPs elicited higher CD4 190 responses than either MP alone (geometric mean $0.25 \%$ vs $0.46 \%$ CD4 AIM+, $p=0.0078$ 191 and $0.36 \%$ vs $0.46 \%$ CD4 $\mathrm{AIM}+, \mathrm{p}=0.004$, respectively by Wilcoxon test) and had the 192 highest magnitude response of all pools tested. This indicates that the combination of 193 known (IEDB-II MP) and novel epitopes and ORFs (P235 MP) can capture the broadest 194 range of CD4 T-cell responses in HCMV+ individuals, which has high potential for clinical 195 diagnostic use. 


\section{Discussion}

In this study we have identified >200 new epitopes derived from 100 HCMV ORFs

201 that induce virus-specific T cell responses. Importantly, this demonstrates that the current

202 HLA peptide-binding prediction algorithms that we and others have refined over the last

203 several decades are extremely efficient (47-51), and represent an excellent alternative to

204 synthesizing genome-wide overlapping peptides, especially for large pathogens such as

205 HCMV. Despite the significant diversity in the human HLA repertoire, current advances in

206 algorithm-based epitope identification take into consideration epitopes with potential

207 binding to diverse haplotypes, which undoubtedly contributed to this success $(40,52)$.

208 Together, this approach allowed us to increase the known T cell epitope landscape for

209 HCMV by greater than 10-fold by synthesizing only 2593 peptides, illustrating both its

210 efficiency and cost effectiveness in deciphering immune targets of large pathogens.

211 We chose to use IFN- $\gamma$ production as a readout for positive epitope reactivity in a

212 fluorospot-based assay to identify HCMV-specific T cell epitopes in this study. As true for

213 most viral infections, CMV drives a strong Th1-like CD4+ response, and most effector

214 and memory viral CD8+ T cells also produce this cytokine (53). However, future studies

215 assessing which of these 235 epitopes may elicit HCMV-specific CD4 T cells to produce

216 other cytokines are merited. Previously, we have observed that Dengue virus epitope-

217 specific CD4+ T cells can produce both IFN $\gamma$ and IL-10 (54), something we have also

218 seen during acute CMV infection in mice (55), where IL-10 producing CD4+ T cells

219 enhance the duration of viral persistence (56). Recent studies by the Wills and Moss

220 groups show that subsets of HCMV epitope-specific CD4+ T cells can produce IL-10 and

221 also display cytolytic markers $(57,58)$. The potential CTL activity of HCMV-specific CD4+ 
222 T cells has been postulated for many years (59), and our recent results showing that CMV

223 epitope-specific CD4 T cells can directly kill in vivo support this hypothesis (60). Taken

224 together, our identification of $>200$ new T cell epitopes that elicit IFN $\gamma$ production in this

225 study provide us and others in the field valuable new tools to dissect the phenotypes and

226 effector functions of HCMV-specific CD4 T cells in cases of both healthy and immune

227 compromised patients, and will also help instruct ongoing vaccine efforts.

228 Of the 100 ORFs which we show here to be sources of specific T cell epitopes, 41

229 were uniquely identified as ribosome-bound RNAs in HCMV infected fibroblasts (39), with

230 these 41 yielding 50 unique epitopes. Notably, of these 41 ORFs, 17 are predicted to

231 produce proteins $<50$ amino acids in length, and 7 contain non-ATG start codons. This is

232 consistent with recent studies suggesting that the short/'cryptic' mRNAs present in both

233 virally infected and tumor cells can be translated, proteolytically processed and loaded

234 onto HLA molecules, resulting in the induction of epitope-specific T cell responses (61-

235 63). Interestingly, one of the larger 41 ORFs that contains two newly identified T cell

236 epitopes (ORFL147C, 476 amino acids) has very recently been shown to regulate RNA

237 binding/processing, and its deletion compromises CMV replication in fibroblasts (64).

238 Despite $>20 \%$ of the novel T cell epitopes identified here being derived from these newly

239 described, ribosome-associated HCMV RNAs, no more than 2 of the 19 healthy donors

240 analyzed produce T cells specific for any single one of these epitopes. This indicates that

241 these novel ORFs 1) may not be broad targets of T cell responses in infected persons, 2)

242 that specific individuals may more efficiently present epitopes derived from short/cryptic

243 HCMV RNAs or 3) that minor HLA molecules may present them, with other possibilities

244 also existing. Additionally, whether the proteins derived from these short ORFs are stable 
245 and play a role in the HCMV lifecycle remains an open question. Finally, we also identified

24624 epitopes derived from 14 'canonical' HCMV ORFs where the only historic support for

247 their existence was the presence of their RNA in infected cells or bioinformatic analyses.

248 Notably, a recent comprehensive study where 169 predicted canonical HCMV proteins

249 (including these 14) were epitope-tagged, expressed stably in infected cells,

250 immunoprecipitated and analyzed for interacting proteins by mass spectrometry supports

251 our results that these ORFs are expressed as proteins (64).

252 Of the 59 canonical ORFs that we have identified here to contain T cell epitopes,

$253>25 \%$ of these are known to function as immunomodulatory proteins (65). This is

254 intriguing, as perhaps these HCMV proteins are more subject to being localized to

255 antigen-processing or presentation compartments within infected cells. One of these

256 epitopes is derived from the HCMV IL-10 orthologue, which is being considered as a

257 potential HCMV vaccine candidate $(66,67)$. Additionally, 3 epitopes were found to be

258 embedded within the viral UL128 protein, a critical component of the pentameric envelope

259 protein complex (UL128-131/gH/gL) that mediates entry of HCMV into non-fibroblast cell

260 types $(68,69)$. This is also of high potential interest in the context of vaccine development,

261 as many believe the pentamer should be included in a viral- or subunit-based approach

262 (70). Notably, both vIL-10 and UL128 have largely been considered only in the context of

263 their abilities to induce antibody-based vaccine protection, but our identification of $\mathrm{T}$ cell

264 epitopes derived from both these HCMV proteins suggests they may function to prime

265 both humoral and cellular immunity.

\section{Methods}




\section{Study design}

For the initial CMV ORF screen, the responses of 19 CMV-seropositive subjects were evaluated. PBMCs were stimulated with 89 pools covering 563 ORFs of HCMV.

271 Each pool comprised of 28-30 15-mer peptides overlapping by 10 residues. PBMCs that

272 were found reactive to a pool were further tested against individual peptides contained in

273 the pool using IFN- $\gamma$ Fluorospot assay. Flow cytometry was then used to further

274 characterize the epitopes recognized by PBMCs stimulated with individual peptides by 275 detecting IFN- $\gamma$ production from CD8+ and CD4+ T cells.

For the CMV-235 validation and comparison screen, the responses of a new cohort

277 consisting of 10 CMV-seropositive and 10 seronegative subjects were evaluated. PBMCs

278 were stimulated with CMV-Mabtech peptide pool (Catalog 3619-1), CMV-IEDB peptide

279 pool (Table 2) $(44,46)$, CMV-235 pool, or a combination of both CMV-IEDB and CMV-

280235 pools. PBMC responses were assayed using the same IFN- $\gamma$ Fluorospot assay.

281 These studies were approved by the institutional review board committee at La Jolla

282 Institute protocol number: VD-112 and VD-174.

\section{Subjects}

19 subjects (10 males and 9 females) were recruited anonymously from San Diego

285 blood bank (SDBB) for the initial CMV ORF screens. For the CMV-235 comparison 286 screens, samples from 20 subjects (6 males and 14 females) were obtained by La Jolla 287 Institute Clinical Core and Continental Services Group (Miami, FL) for prior, unrelated 288 studies. Blood samples were collected by trained staff. At the time of enrollment in the 289 initial studies, all individual subjects provided informed consent that any leftover sample 290 could be used for future studies, which includes this study. These subjects were 
291 considered healthy as defined by no known history of any significant systemic diseases

292 (not limited to autoimmune disease, diabetes, kidney or liver disease, congestive heart

293 failure, malignancy, coagulopathy, hepatitis B or C, or HIV). The demographics of those

294 subjects are provided in Table 3.

295 The IgG antibodies of the subjects for both cohorts were measured using 296 Cytomegalovirus IgG Elisa kit from Genway Biotech Inc. according to manufacturer's 297 instructions.

\section{Peptide prediction}

299 Based on the 7-allele method as previously described (40), 2593 peptides were 300 predicted for 563 potential HCMV ORFs. Of the 751 ORFs predicted by ribosomal 301 profiling (39), those smaller than 15 amino acids were excluded, and only one peptide of

302 ORFs 15-20 amino acids in length were selected for screening.

\section{Peptide libraries and pool preparation}

The predicted peptides were commercially synthesized as crude material by TC

305 Peptide Lab (www.tcpeptidelab.com; San Diego, CA). The peptides were solubilized in

306 DMSO at a concentration of $20 \mathrm{mg} / \mathrm{ml}$ and spot checked for quality by mass spectrometry.

307 The peptides were pooled into peptide pools containing 28-30 peptides constituting 308 multiple ORFs per pool. A total of 89 pools were prepared covering 563 ORFs of HCMV.

309 The final concentration of each pool was $0.7 \mathrm{mg} / \mathrm{ml}$.

For the IEDB-II (Table 2) and P235 (Table 1) peptide pools peptides were

311 synthesized by A\&A Itd, San Diego, resuspended in DMSO, pooled and sequentially

312 lyophilized as previously described (71). The IEDB-II peptide pool was developed based

313 on data available in the IEDB (www.iedb.org) (41). The MHC class II restricted epitopes 
314 for CMV was extracted from the IEDB in October of 2020 using the following query;

315 Organism: human herpesvirus 5 (ID:10359), positive assays only, no B cell assays, MHC

316 restriction type: class II, host: Homo sapiens. The resulting 187 epitopes (table 2) were

317 filtered for size (13-20 amino acids) and discovered using one of the following assays:

318 ELISPOT, ICS, multi- or tetramers, proliferation and "helper response". The CMV peptide

319 pool for human CD4 and CD8 T cells containing 42 peptides (14 MHC class II restricted

320 and $28 \mathrm{MHC}$ class I restricted) representing pp50, pp65, IE1, IE2, and envelope

321 glycoprotein B was purchased from Mabtech.

\section{Isolation of PBMC by Ficoll-Paque density gradient centrifugation}

323 One-unit blood from each donor was processed for PBMC isolation. Briefly, blood

324 was centrifuged and the top layer of plasma was removed. The remaining blood was

325 diluted and layered over $15 \mathrm{ml}$ of Ficoll-Paque. Tubes were spun at room temperature in

326 a swinging bucket rotor without brake applied. The PBMC interface was carefully removed

327 by pipetting and washed with PBS by centrifugation at 800 rpm for 10 mins with brakes

328 off. PBMC pellet was resuspended in RPMI media, cell number and viability were

329 determined by trypan blue staining and cells were cryopreserved in liquid nitrogen in

330 freezing media (90\% Fetal bovine serum and 10\% DMSO) at a density of $30 \mathrm{million} / \mathrm{ml}$

331 and stored until further processed.

\section{Fluorospot assay}

333 PBMC were thawed, washed and counted for viability using the trypan blue

334 exclusion method. 200,000 cells were plated in triplicates and stimulated with pools

$335(2 \mu \mathrm{g} / \mathrm{ml})$ or peptides $(10 \mu \mathrm{g} / \mathrm{ml})$, PHA $(10 \mu \mathrm{g} / \mathrm{ml})$ or medium containing equivalent amount

336 of DMSO in 96- well plates (Immubilion-P, Millipore) previously coated with anti IFN- $\gamma$ 
337 antibody (1-D1K, Mabtech, Stockholm, Sweden). After $20 \mathrm{hr}$ incubation at $37^{\circ} \mathrm{C}$, cells

338 were discarded and wells were washed six times with PBS/0.05\% Tween 20 using an

339 automated plate washer and further incubated with IFN- $\gamma$ antibody (7-B6-1-FS-BAM) for

3402 hrs at room temperature. After incubation, wells were washed and incubated with

341 fluorophore conjugated anti-BAM-490 antibody for $1 \mathrm{hr}$ at room temperature. Finally, the

342 plates were washed and incubated with fluorescence enhancer for 15 min, blotted dry

343 and fluorescent spots were counted by computer assisted image analysis (IRIS

344 Fluorospot reader, Mabtech, Sweden).

345 Each pool or peptide was considered positive compared to the background that

346 had equivalent amount of DMSO based on the following criteria: (i) 20 or more spot

347 forming cells (SFC) per $10^{6}$ PBMC after background subtraction, (ii) the stimulation index

348 greater than 2, and (iii) $\mathrm{p}<0.05$ by student's $t$ test or Poisson distribution test when

349 comparing the peptide or pool triplicates with the negative control triplicate.

350 Intracellular cytokine assay for IFN- $\gamma$

351 Intracellular staining for IFN- $\gamma$ and flow cytometry was performed to detect antigen

352 specific T cell responses. $1 \times 10^{6}$ PBMCs suspended in RPMI medium supplemented with

$3531-\%$ heat inactivated human AB serum, glutamine and penicillin streptomycin were plated

354 in U-bottom 96 well plates. After overnight resting at $37^{\circ} \mathrm{C}, \mathrm{PBMCs}$ were spun and

355 replaced with fresh RPMI media and stimulated with individual peptides at a concentration

356 of $10 \mu \mathrm{g} / \mathrm{ml}$. PHA at a concentration of $5 \mu \mathrm{g} / \mathrm{ml}$ was used as a positive control. After $1 \mathrm{hr}$

357 of incubation at $37^{\circ} \mathrm{C}, 2 \mu \mathrm{g} / \mathrm{ml}$ of Brefeldin was added and cell were further incubated at

$35837^{\circ} \mathrm{C}$ for additional $5 \mathrm{hrs}$. The cells were then harvested, washed with $200 \mu \mathrm{l}$ of MACS

359 Buffer and stained with a cocktail of antibodies that contained CD3-Af700 (eBioscience, 
360 clone UCHT1), CD4-APCef780 (eBioscience, clone RPA-T4), CD8-BV650 (Biolegend,

361 clone RPA-T8), CD14-V500 (BD Biosciences, clone M5E2), CD19-V500 (BD

362 Biosciences, clone HIB19), and fixable viability dye-e506 for 30 min at $4^{\circ} \mathrm{C}$. The cells

363 were then washed thrice with $200 \mu$ l MACS buffer, fixed using $4 \%$ PFA for 10 mins at $4^{\circ} \mathrm{C}$,

364 washed with $200 \mu \mathrm{l}$ PBS and rested at $4^{\circ} \mathrm{C}$ overnight in $200 \mu \mathrm{l}$ MACS buffer. The following

365 day, cells were washed, permeabilized by washing with $200 \mu$ l saponin buffer $(0.5 \%$

366 saponin in PBS), washed with blocking buffer (10\% human serum prepared in saponin

367 buffer) and stained with IFN- $\gamma$-FITC (eBioscience, clone 4S.B3) antibody at room

368 temperature for 30 mins. The cells were finally washed with PBS and suspended in 200

$369 \mu$ P PBS.

$370 \quad$ The cells were acquired on ZE5 Biorad plate reader and further analysis was done

371 on FlowJo software. Gates were applied on live single cells for CD3+, CD4+ and CD8+ T

372 cell populations. The percentage of reactive CD4+ or CD8+ IFN- $\gamma$ T cells were expressed

373 as a percent of the total number of parent population analyzed. Reactive populations met

374 the following 2 criteria: (i) well-defined cell population positive for both IFN- $\gamma$ and CD4 or

375 CD8 constituting at least $0.02 \%$ (post subtracting their corresponding DMSO controls) of

376 the total number of CD4+ or CD8+ cells analyzed (ii) stimulation index greater than 2.

\section{Activation induced marker (AIM) assay}

378 PBMC were thawed, washed and counted for viability using the trypan blue

379 exclusion method. 1 million cells per donor/condition were plated and cultured in the 380 presence of the CMV specific pools $(1 \mu \mathrm{g} / \mathrm{mL}$ for P235 and IEDB-II, $2 \mu \mathrm{g} / \mathrm{mL}$ for Mabtech

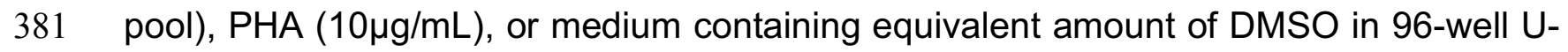
382 bottom plates. Cells were then harvested, washed with $200 \mu$ l of MACS Buffer and stained 
383 with a cocktail of antibodies that contained CD3-Af700 (eBioscience, clone UCHT1), CD4-

384 BV605 (eBioscience, clone RPA-T4), CD8-PerCP-Cy5.5 (Biolegend, clone HIT8a),

385 CD14-V500 (BD Biosciences, clone M5E2), CD19-V500 (BD Biosciences, clone HIB19),

386 OX40-PE-Cy7 (Ber-ACT35), CD137-APC (4B4-1), and fixable viability dye-e506 for 30

$387 \min$ at $4^{\circ} \mathrm{C}$. The cells were then washed thrice with $200 \mu$ l MACS buffer, fixed using $4 \%$

388 PFA for 10 mins at $4^{\circ} \mathrm{C}$, and resuspended in $200 \mu$ l of PBS for acquisition.

389 Cells were acquired on a BD LSRFortessa and further analysis was done on

390 FlowJo software. As previously described $(44,72)$, quantification of live, singlet antigen

391 specific CD4 T cells was determined as a percentage of their OX40+CD137+ expression

392 (AIM+). CMV specific AIM+ CD4 T cell signals were background subtracted with their

393 corresponding negative control DMSO samples, with a minimal DMSO level set to

$3940.005 \%$. The limit of detection (LOD) for the AIM+ assay was calculated by multiplying

395 the upper confidence interval of the geometric mean of all DMSO samples by $2(0.03)$.

396 Statistical analysis

397 Statistical analyses were performed using GraphPad Prism versions 8.1.1 and

398 8.4.3. Statistical details are provided with each figure. 


\section{Acknowledgement}

407 We would also like to thank all donors that participated in the study. We also thank the

408 La Jolla Institute for Immunology Clinical Studies Group and Flow Cytometry Core for all

409 the invaluable help.

\section{Author contribution}

412 AS and CAB conceived the study. RD and GW performed the experiments and

413 analyzed the data. SKD performed peptide prediction, JP processed blood samples,

414 RD, GW, and GP conducted ELISA, JS helped with the quality check of synthesized

415 peptides, AG designed the IEDB-II pool, CLA, AS, CAB directed the study, RD, AS,

416 CAB wrote the manuscript taking input from other authors.

418 Funding

419 This work was supported by NIH Grants Al139749 and Al101423 to C.A.B, and NIH

420 contracts 75 N93019C00065 to A.S. and 75N93019C00067 to C.L.A.

\section{Conflict of interest}

423 The authors declare that they have no conflict of interest. 


\section{References}

431 1. Collins-McMillen D, Buehler J, Peppenelli M, Goodrum F. 2018. Molecular 
13. Jeon J, Victor M, Adler SP, Arwady A, Demmler G, Fowler K, Goldfarb J, Keyserling H, Massoudi M, Richards K, Staras SA, Cannon MJ. 2006. Knowledge and awareness of congenital cytomegalovirus among women. Infect Dis Obstet Gynecol 2006:80383. 
28. Reusser P, Riddell SR, Meyers JD, Greenberg PD. 1991. Cytotoxic T-lymphocyte response to cytomegalovirus after human allogeneic bone marrow transplantation: pattern of recovery and correlation with cytomegalovirus infection and disease. Blood 78:1373-

29. Smith CJ, Quinn M, Snyder CM. 2016. CMV-Specific CD8 T Cell Differentiation and Localization: Implications for Adoptive Therapies. Front Immunol 7:352.

30. Sylwester AW, Mitchell BL, Edgar JB, Taormina C, Pelte C, Ruchti F, Sleath PR, Grabstein KH, Hosken NA, Kern F, Nelson JA, Picker LJ. 2005. Broadly targeted human cytomegalovirus-specific CD4+ and CD8+ T cells dominate the memory compartments of exposed subjects. J Exp Med 202:673-85.

31. Kern F, Bunde T, Faulhaber N, Kiecker F, Khatamzas E, Rudawski IM, Pruss A, Gratama JW, Volkmer-Engert R, Ewert R, Reinke P, Volk HD, Picker LJ. 2002. Cytomegalovirus (CMV) phosphoprotein 65 makes a large contribution to shaping the $\mathrm{T}$ cell repertoire in CMV-exposed individuals. J Infect Dis 185:1709-16.

32. Kern F, Surel IP, Faulhaber N, Frommel C, Schneider-Mergener J, Schonemann C, Reinke P, Volk HD. 1999. Target structures of the CD8(+)-T-cell response to human cytomegalovirus: the 72-kilodalton major immediate-early protein revisited. J Virol 73:8179-84.

33. Khan N, Best D, Bruton R, Nayak L, Rickinson AB, Moss PA. 2007. T cell recognition patterns of immunodominant cytomegalovirus antigens in primary and persistent infection. J Immunol 178:4455-65.

34. Khan N, Cobbold M, Keenan R, Moss PA. 2002. Comparative analysis of CD8+ T cell responses against human cytomegalovirus proteins pp65 and immediate early 1 shows similarities in precursor frequency, oligoclonality, and phenotype. J Infect Dis 185:102534.

35. Elkington R, Walker S, Crough T, Menzies M, Tellam J, Bharadwaj M, Khanna R. 2003. Ex vivo profiling of CD8+-T-cell responses to human cytomegalovirus reveals broad and multispecific reactivities in healthy virus carriers. J Virol 77:5226-40.

36. Elkington R, Shoukry NH, Walker S, Crough T, Fazou C, Kaur A, Walker CM, Khanna R. 2004. Cross-reactive recognition of human and primate cytomegalovirus sequences by human CD4 cytotoxic T lymphocytes specific for glycoprotein B and H. Eur J Immunol 34:3216-26.

37. Paston SJ, Dodi IA, Madrigal JA. 2004. Progress made towards the development of a CMV peptide vaccine. Hum Immunol 65:544-9.

38. Fuhrmann S, Streitz M, Reinke P, Volk HD, Kern F. 2008. T cell response to the cytomegalovirus major capsid protein (UL86) is dominated by helper cells with a large polyfunctional component and diverse epitope recognition. J Infect Dis 197:1455-8.

39. Stern-Ginossar N, Weisburd B, Michalski A, Le VT, Hein MY, Huang SX, Ma M, Shen B, Qian SB, Hengel H, Mann M, Ingolia NT, Weissman JS. 2012. Decoding human cytomegalovirus. Science 338:1088-93.

40. Paul S, Lindestam Arlehamn CS, Scriba TJ, Dillon MB, Oseroff C, Hinz D, McKinney DM, Carrasco Pro S, Sidney J, Peters B, Sette A. 2015. Development and validation of a broad scheme for prediction of HLA class II restricted T cell epitopes. J Immunol Methods 422:28-34. 
41. Vita R, Mahajan S, Overton JA, Dhanda SK, Martini S, Cantrell JR, Wheeler DK, Sette A, Peters B. 2019. The Immune Epitope Database (IEDB): 2018 update. Nucleic Acids Res 47:D339-D343.

42. Bancroft T, Dillon MB, da Silva Antunes R, Paul S, Peters B, Crotty S, Lindestam Arlehamn CS, Sette A. 2016. Th1 versus Th2 T cell polarization by whole-cell and acellular childhood pertussis vaccines persists upon re-immunization in adolescence and adulthood. Cell Immunol 304-305:35-43.

43. da Silva Antunes R, Paul S, Sidney J, Weiskopf D, Dan JM, Phillips E, Mallal S, Crotty S, Sette A, Lindestam Arlehamn CS. 2017. Definition of Human Epitopes Recognized in Tetanus Toxoid and Development of an Assay Strategy to Detect Ex Vivo Tetanus CD4+ T Cell Responses. PLoS One 12:e0169086.

44. Grifoni A, Weiskopf D, Ramirez SI, Mateus J, Dan JM, Moderbacher CR, Rawlings SA, Sutherland A, Premkumar L, Jadi RS, Marrama D, de Silva AM, Frazier A, Carlin AF, Greenbaum JA, Peters B, Krammer F, Smith DM, Crotty S, Sette A. 2020. Targets of T Cell Responses to SARS-CoV-2 Coronavirus in Humans with COVID-19 Disease and Unexposed Individuals. Cell 181:1489-1501 e15.

45. Lindestam Arlehamn CS, McKinney DM, Carpenter C, Paul S, Rozot V, Makgotlho E, Gregg Y, van Rooyen M, Ernst JD, Hatherill M, Hanekom WA, Peters B, Scriba TJ, Sette A. 2016. A Quantitative Analysis of Complexity of Human Pathogen-Specific CD4 T Cell Responses in Healthy M. tuberculosis Infected South Africans. PLoS Pathog 12:e1005760.

46. Mateus J, Grifoni A, Tarke A, Sidney J, Ramirez SI, Dan JM, Burger ZC, Rawlings SA, Smith DM, Phillips E, Mallal S, Lammers M, Rubiro P, Quiambao L, Sutherland A, Yu ED, da Silva Antunes R, Greenbaum J, Frazier A, Markmann AJ, Premkumar L, de Silva A, Peters B, Crotty S, Sette A, Weiskopf D. 2020. Selective and cross-reactive SARSCoV-2 T cell epitopes in unexposed humans. Science 370:89-94.

47. Nielsen M, Justesen S, Lund O, Lundegaard C, Buus S. 2010. NetMHCIIpan-2.0 Improved pan-specific HLA-DR predictions using a novel concurrent alignment and weight optimization training procedure. Immunome Res 6:9.

48. Nielsen M, Lund O. 2009. NN-align. An artificial neural network-based alignment algorithm for MHC class II peptide binding prediction. BMC Bioinformatics 10:296.

49. Paul S, Kolla RV, Sidney J, Weiskopf D, Fleri W, Kim Y, Peters B, Sette A. 2013. Evaluating the immunogenicity of protein drugs by applying in vitro MHC binding data and the immune epitope database and analysis resource. Clin Dev Immunol 2013:467852.

50. Salimi N, Fleri W, Peters B, Sette A. 2012. The immune epitope database: a historical retrospective of the first decade. Immunology 137:117-23.

51. Wang P, Sidney J, Kim Y, Sette A, Lund O, Nielsen M, Peters B. 2010. Peptide binding predictions for HLA DR, DP and DQ molecules. BMC Bioinformatics 11:568.

52. Dhanda SK, Karosiene E, Edwards L, Grifoni A, Paul S, Andreatta M, Weiskopf D, Sidney J, Nielsen M, Peters B, Sette A. 2018. Predicting HLA CD4 Immunogenicity in Human Populations. Front Immunol 9:1369.

53. Lim EY, Jackson SE, Wills MR. 2020. The CD4+ T Cell Response to Human Cytomegalovirus in Healthy and Immunocompromised People. Front Cell Infect Microbiol 10:202.

54. Tian Y, Seumois G, De-Oliveira-Pinto LM, Mateus J, Herrera-de la Mata S, Kim C, Hinz D, Goonawardhana NDS, de Silva AD, Premawansa S, Premawansa G, Wijewickrama A, 
Balmaseda A, Grifoni A, Vijayanand P, Harris E, Peters B, Sette A, Weiskopf D. 2019. Molecular Signatures of Dengue Virus-Specific IL-10/IFN-gamma Co-producing CD4 T Cells and Their Association with Dengue Disease. Cell Rep 29:4482-4495 e4.

55. Wehrens EJ, Wong KA, Gupta A, Khan A, Benedict CA, Zuniga EI. 2018. IL-27 regulates the number, function and cytotoxic program of antiviral CD4 T cells and promotes cytomegalovirus persistence. PLoS One 13:e0201249.

56. Humphreys IR, de Trez C, Kinkade A, Benedict CA, Croft M, Ware CF. 2007. Cytomegalovirus exploits IL-10-mediated immune regulation in the salivary glands. J Exp Med 204:1217-25.

57. Jackson SE, Sedikides GX, Mason GM, Okecha G, Wills MR. 2017. Human Cytomegalovirus (HCMV)-Specific CD4(+) T Cells Are Polyfunctional and Can Respond to HCMV-Infected Dendritic Cells In Vitro. J Virol 91.

58. Pachnio A, Ciaurriz M, Begum J, Lal N, Zuo J, Beggs A, Moss P. 2016. Cytomegalovirus Infection Leads to Development of High Frequencies of Cytotoxic Virus-Specific CD4+ T Cells Targeted to Vascular Endothelium. PLoS Pathog 12:e1005832.

59. van Leeuwen EM, Remmerswaal EB, Vossen MT, Rowshani AT, Wertheim-van Dillen PM, van Lier RA, ten Berge IJ. 2004. Emergence of a CD4+CD28-granzyme B+, cytomegalovirus-specific $\mathrm{T}$ cell subset after recovery of primary cytomegalovirus infection. J Immunol 173:1834-41.

60. Verma S, Weiskopf D, Gupta A, McDonald B, Peters B, Sette A, Benedict CA. 2016. Cytomegalovirus-Specific CD4 T Cells Are Cytolytic and Mediate Vaccine Protection. J Virol 90:650-8.

61. Erhard F, Dolken L, Schilling B, Schlosser A. 2020. Identification of the Cryptic HLA-I Immunopeptidome. Cancer Immunol Res 8:1018-1026.

62. Erhard F, Halenius A, Zimmermann C, L'Hernault A, Kowalewski DJ, Weekes MP, Stevanovic S, Zimmer R, Dolken L. 2018. Improved Ribo-seq enables identification of cryptic translation events. Nat Methods 15:363-366.

63. Laumont CM, Perreault C. 2018. Exploiting non-canonical translation to identify new targets for T cell-based cancer immunotherapy. Cell Mol Life Sci 75:607-621.

64. Nobre LV, Nightingale K, Ravenhill BJ, Antrobus R, Soday L, Nichols J, Davies JA, Seirafian S, Wang EC, Davison AJ, Wilkinson GW, Stanton RJ, Huttlin EL, Weekes MP. 2019. Human cytomegalovirus interactome analysis identifies degradation hubs, domain associations and viral protein functions. Elife 8.

65. Picarda G, Benedict CA. 2018. Cytomegalovirus: Shape-Shifting the Immune System. J Immunol 200:3881-3889.

66. Deere JD, Chang WLW, Villalobos A, Schmidt KA, Deshpande A, Castillo LD, Fike J, Walter MR, Barry PA, Hartigan-O'Connor DJ. 2019. Neutralization of rhesus cytomegalovirus IL-10 reduces horizontal transmission and alters long-term immunity. Proc Natl Acad Sci U S A 116:13036-13041.

67. Eberhardt MK, Deshpande A, Chang WL, Barthold SW, Walter MR, Barry PA. 2013. Vaccination against a virus-encoded cytokine significantly restricts viral challenge. $\mathrm{J}$ Virol 87:11323-31.

68. Nguyen CC, Kamil JP. 2018. Pathogen at the Gates: Human Cytomegalovirus Entry and Cell Tropism. Viruses 10. 
652 69. Vanarsdall AL, Johnson DC. 2012. Human cytomegalovirus entry into cells. Curr Opin 653 Virol 2:37-42.

654 70. Gerna G, Lilleri D. 2019. Human cytomegalovirus (HCMV) infection/re-infection: development of a protective HCMV vaccine. New Microbiol 42:1-20.

659 72. Dan JM, Mateus J, Kato Y, Hastie KM, Yu ED, Faliti CE, Grifoni A, Ramirez SI, Haupt

71. Carrasco Pro S, Sidney J, Paul S, Lindestam Arlehamn C, Weiskopf D, Peters B, Sette A. 2015. Automatic Generation of Validated Specific Epitope Sets. J Immunol Res 2015:763461.

664

665

666

667

668 


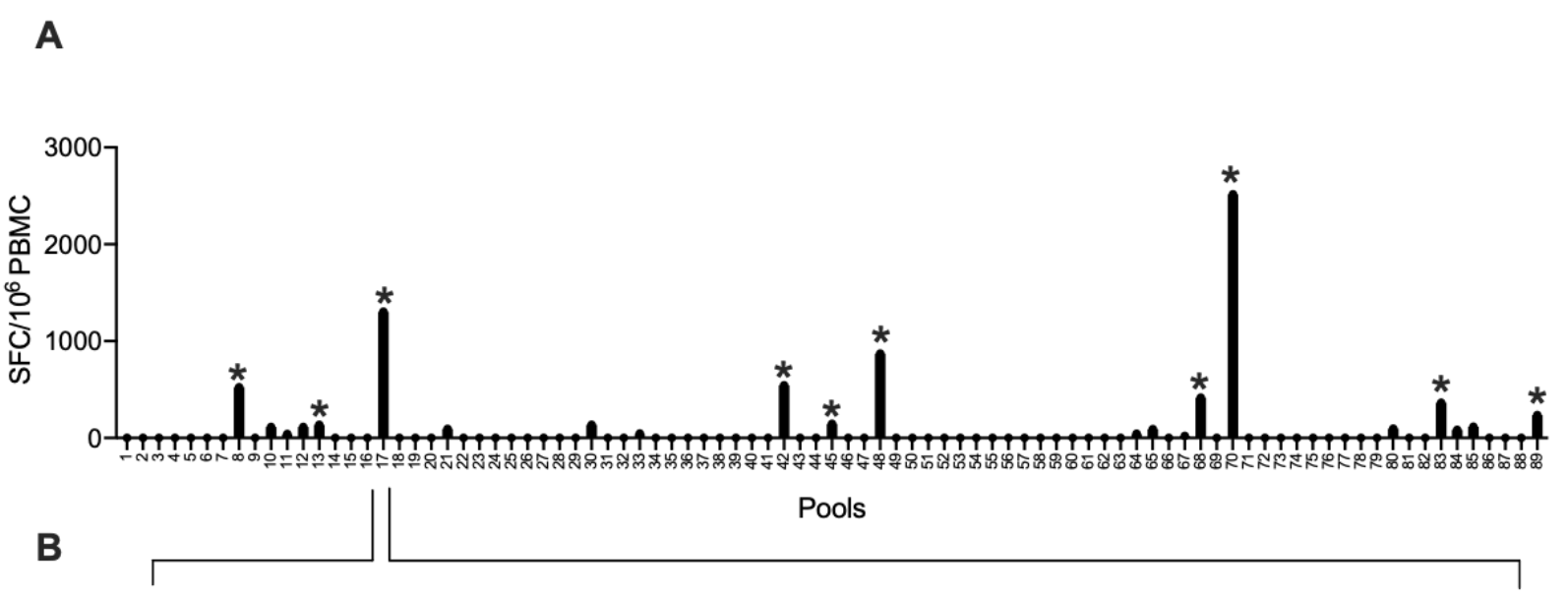

Pool 17

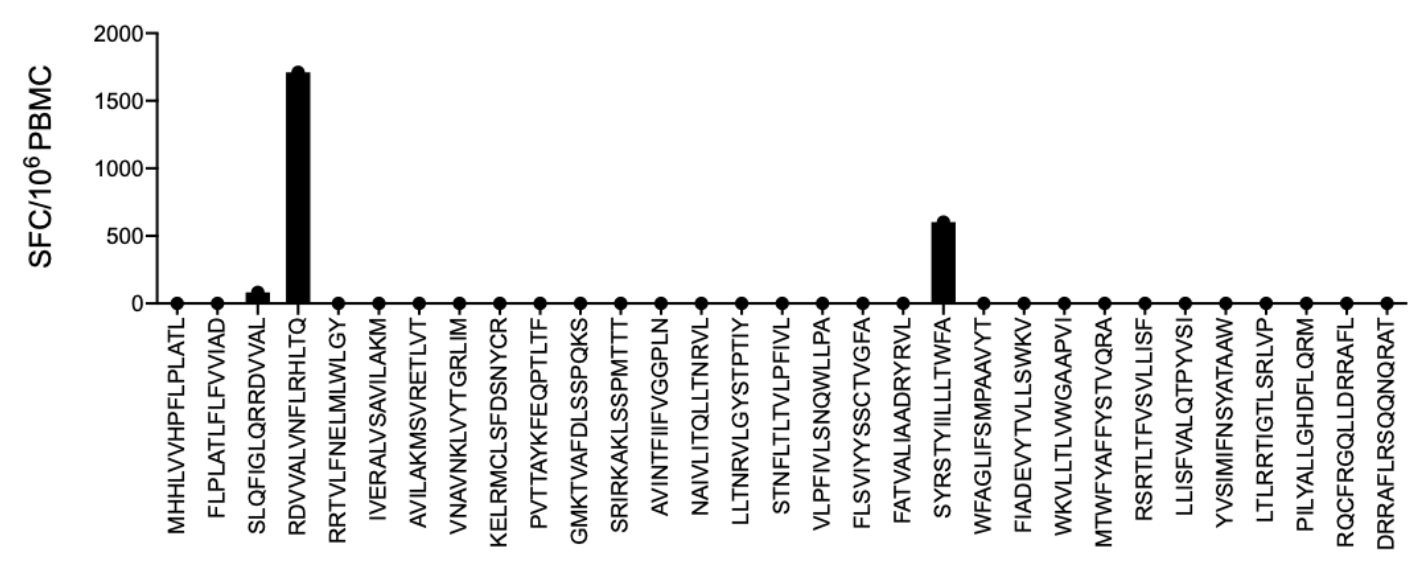

671 Fig. 1 Strategy for HCMV epitope-specific T cell identification: PBMCs from HCMV

672 seropositive subjects were stimulated with $2 \mu \mathrm{g} / \mathrm{ml}$ pools and plated on IFN- $\gamma$ coated

673 fluorospot plates for 20 hours. The top 10 positive pools (indicated by * on bars) were

674 deconvoluted to identify individual epitopes. PBMC were stimulated with $10 \mu \mathrm{g} / \mathrm{ml}$ of each

675 individual peptide contained in the pool and reactivity was measured by IFN- $\gamma$ fluorospot

676 assay. (A) SFC/106 PBMC for one representative subject against the 89 peptide pools (B)

677 Deconvoluted pool representing individual peptides. 
A

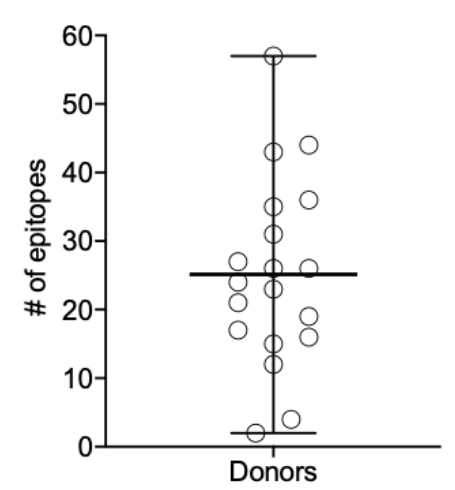

C

679

680

681

682

683

684

685

686

687

688

689

690

691

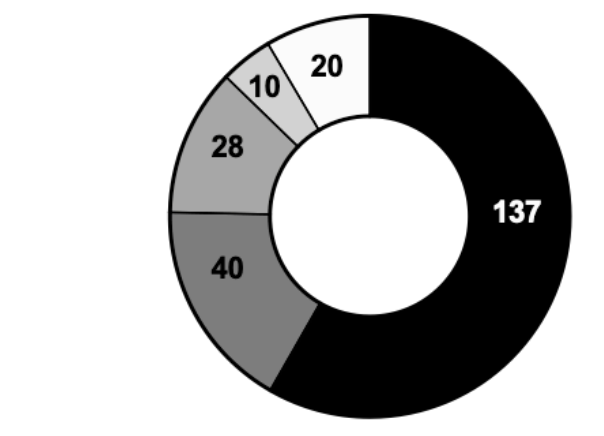

B

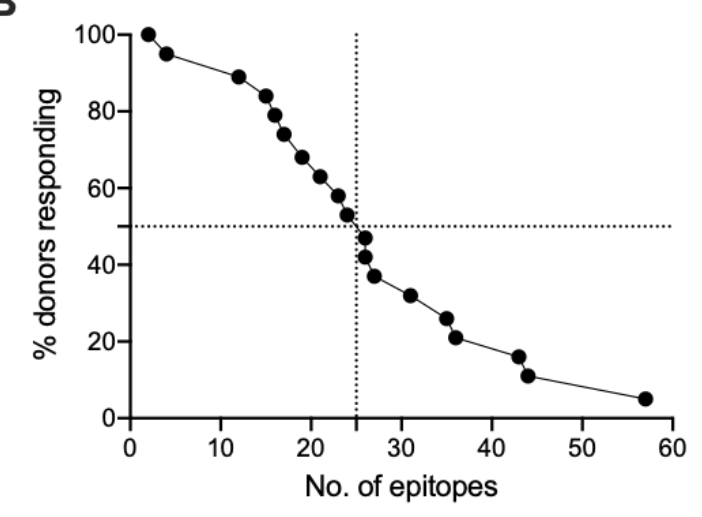

D $\%$ of Response

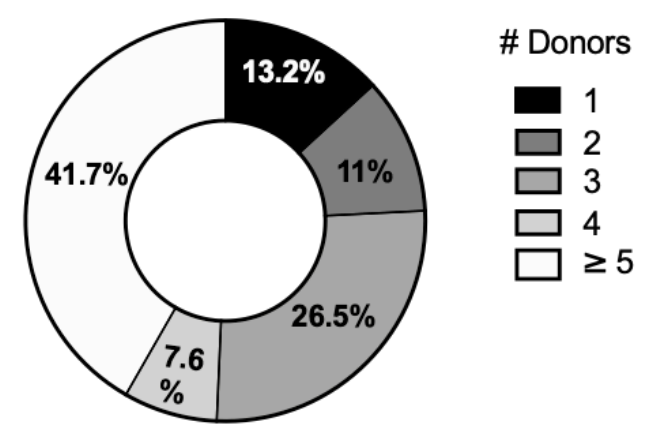

Fig. 2 Breadth and dominance of HCMV T cell responses: (A) The number of epitopes recognized by each donor, mean \pm range. (B) Proportion of the 19 donors that responded to the indicated number of epitopes. (C) Epitopes by number of responding donors. (D) epitope $\%$ of total response by number of responding donors.

\# Donors

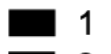

$\square 2$

$\square 3$

$\square 4$

$\geq 5$

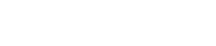


A
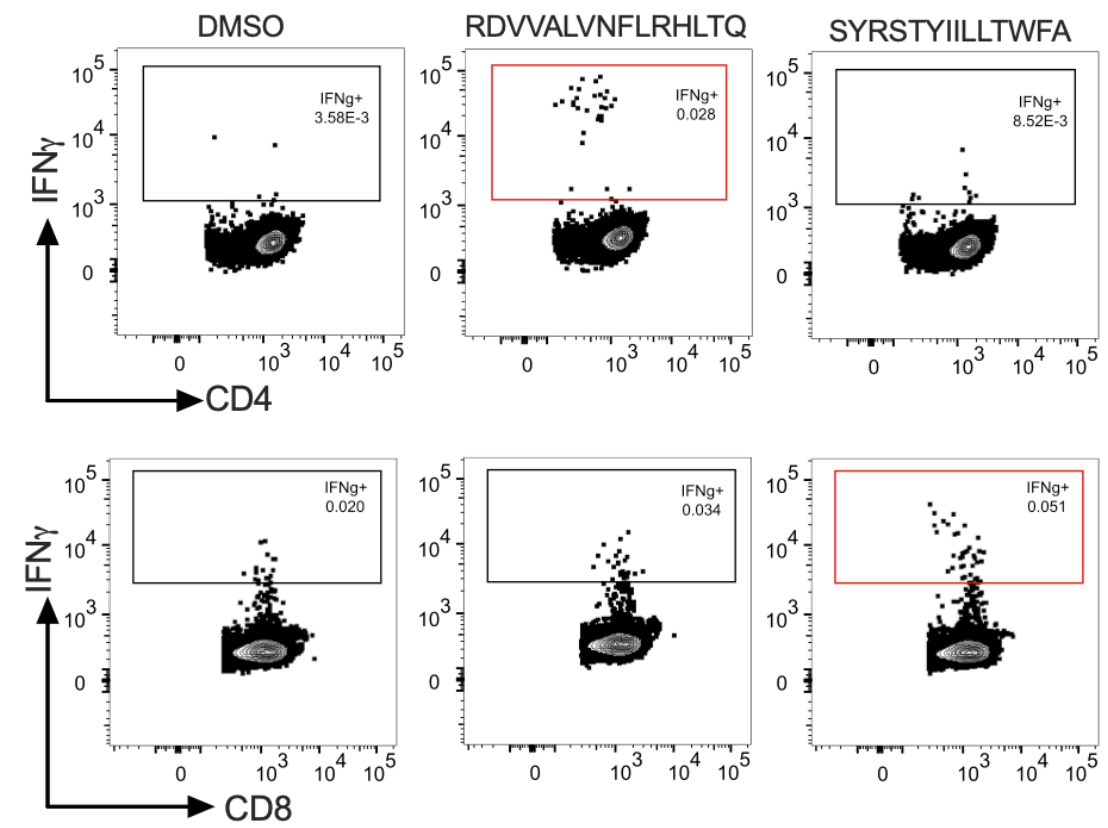

B

\# of events

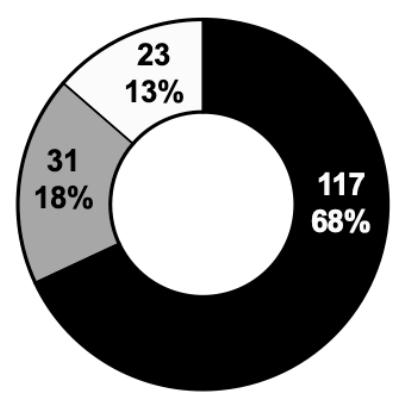

C

$\%$ of IFN $\gamma$ response
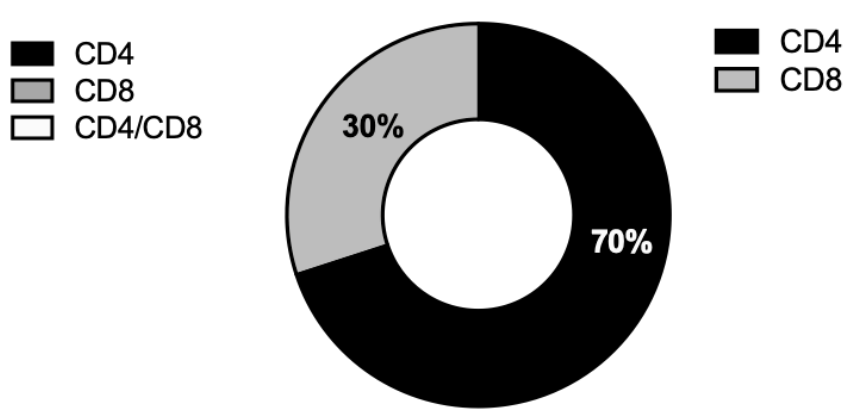

693 Fig. 3 Phenotypic characterization of HCMV T cell responses: (A) Representative

694 FACS plots for intracellular IFN- $\gamma$ production by CD4+ and CD8+ T cells (gating axis in

695 red) upon stimulation with two of the scoring peptide epitopes that induced them (B and

696 C). The number of events and \% response attributable to CD4+ and CD8+ T cell

697 responses of dominant epitopes $(n=58)$ that demonstrated response frequency of 0.15

698 (15\%) (i.e recognized by 3 or more donors). 


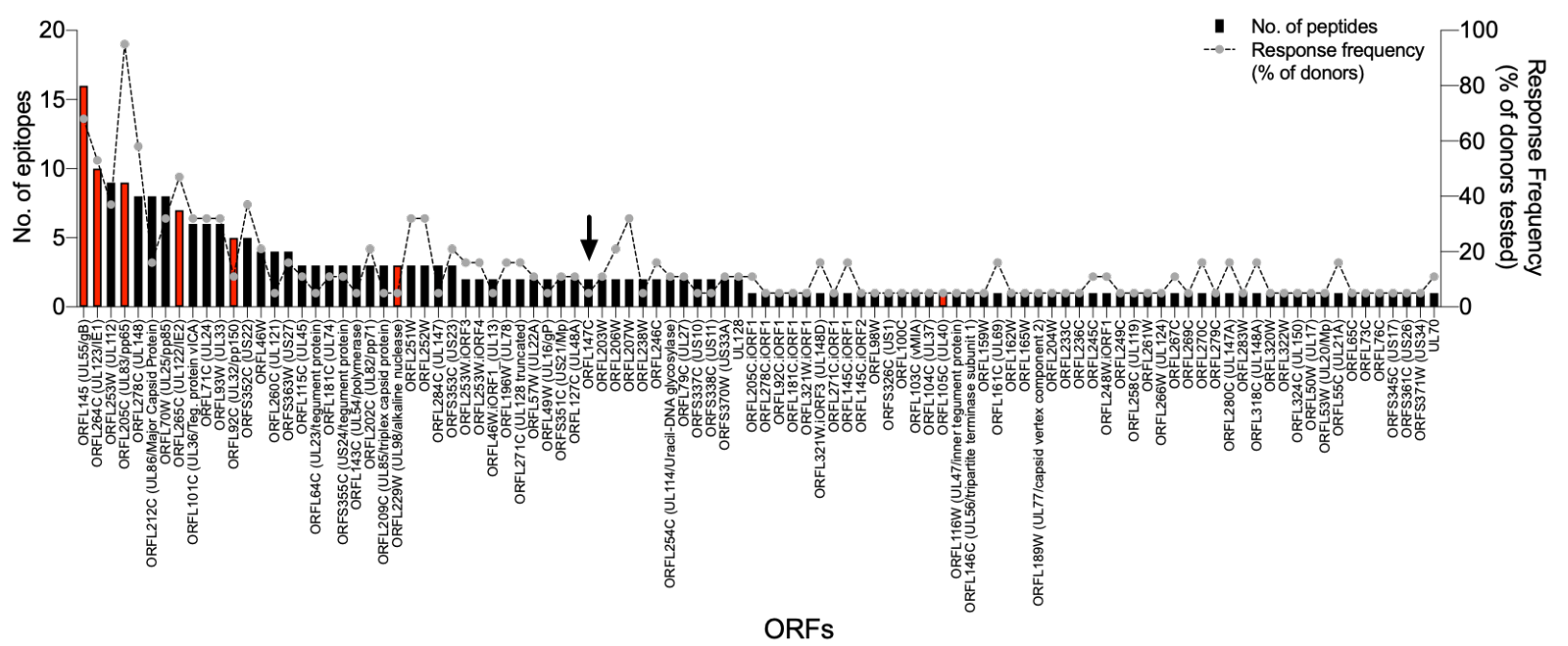

700 Fig. 4 T cell epitope distribution by ORF of origin: 235 epitopes mapped to 100

701 ORFs. Left $Y$ axis denotes the number of epitopes associated with each ORF (bars) and

702 right $\mathrm{Y}$ axis denotes the response frequency associated with each ORF (dotted line).

703 Seven canonical ORFs that were common in IEDB and the present screen are denoted

704 in red. ORFL147C (arrow) is the first 'novel' ORF identified by rRNA profiling from left-

705 to-right, and only induces responses in 2/19 individuals tested. 


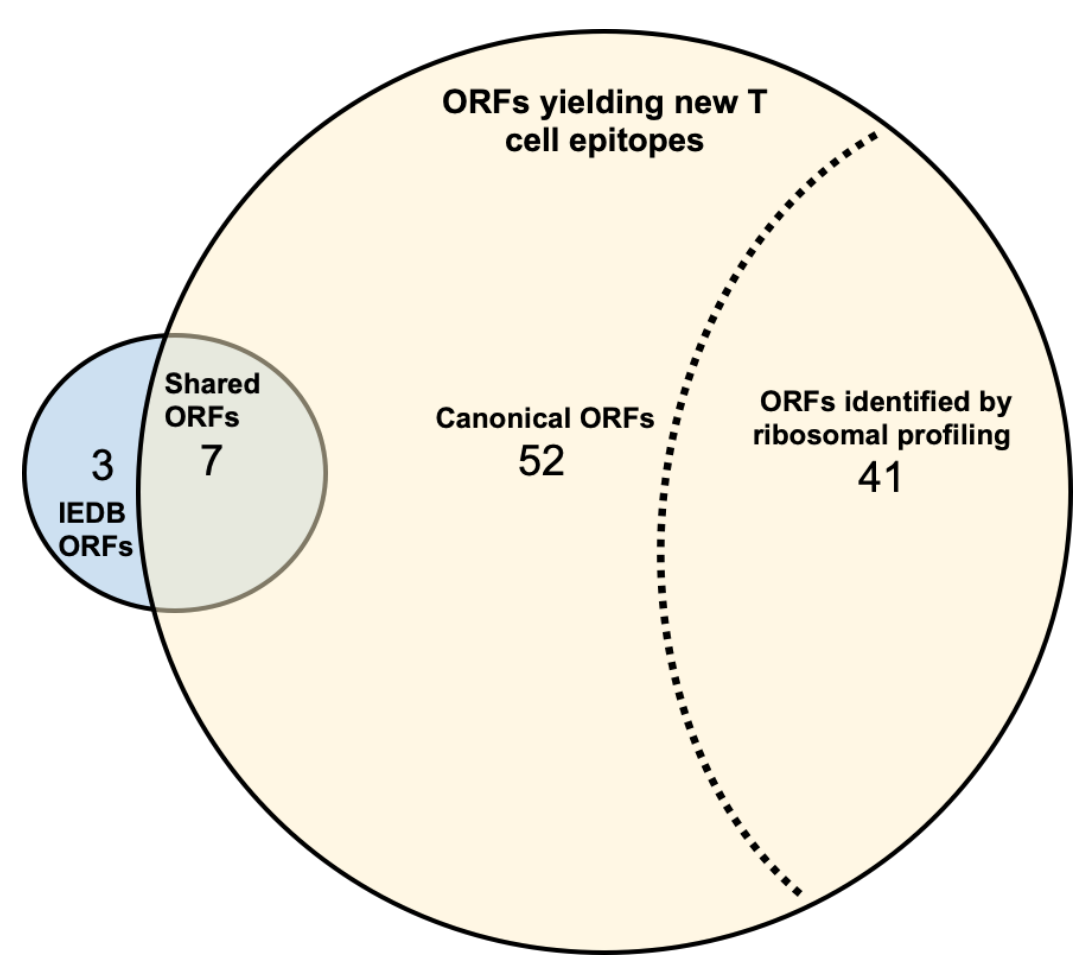

711 Fig. 5 Overlap between IEDB-reported and new immunogenic ORFs identified in

712 this T cell epitope screen. New epitopes were identified in all 100 ORFS, including 7

713 ORFs previously reported in the IEDB to be targets of T cell responses. Of the 93 ORFs

714 found to be new targets of T cells, 52 were canonical and 41 were 'novel' as identified

715 by recent ribosomal mRNA profiling studies. 
A.

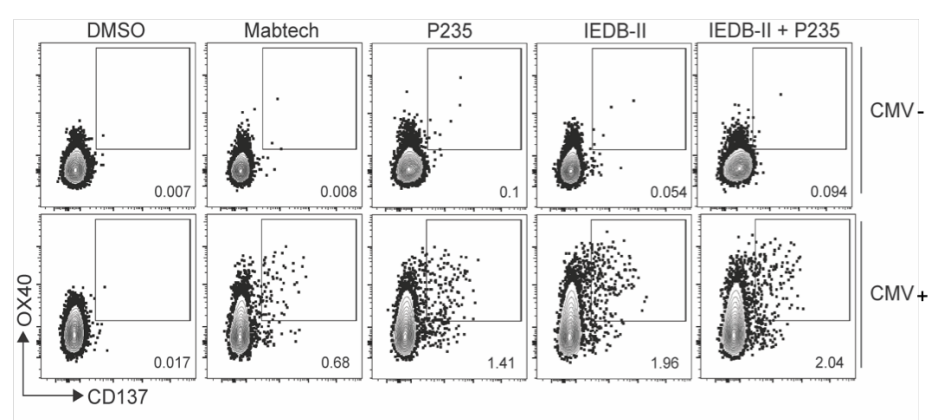

B.

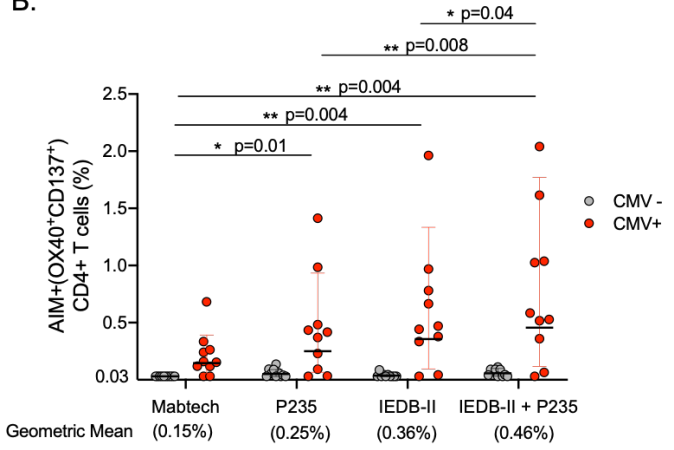

723 Fig. 6 Epitope specific CD4+ T cell responses in HCMV+ and HCMV- subjects

724 detected with different peptide pools: (A) Representative FACS plots showing HCMV

725 specific CD4+ T cell reactivity against different peptide pools based on activation-induced

726 marker assays (OX40+ and CD137+ double expression). PBMCs from HCMV+ (red

727 circles) and CMV- donors (grey circles) were stimulated with $2 \mu \mathrm{g} / \mathrm{ml}$ of the Mabtech pool

728 or IEDB-II/P235 pools for 24 hrs. (B) Epitope-pool specific CD4+ T cells measured as

729 percentage of activation-induced marker assay positive (OX40+CD137+) CD4+ T cells.

730 Each dot represents an individual subject. HCMV+ subjects demonstrated significantly

731 higher CD4+ T cell AIM responses than HCMV- subjects with all the different pools tested.

732 Mabtech HCMV+ vs HCMV- $p=0.0007$; P235 HCMV+ vs HCMV- $p=0.0065$; IEDB-II

$733 \mathrm{CMV}+$ vs CMV- $\mathrm{p}=0.0009$; P235/IEDB-II CMV+ vs CMV- $p=0.004$. Two-tailed Mann-

734 Whitney test. Comparisons across different pool formulations within the CMV+ were

735 made using the Wilcoxon matched-pairs signed ranked test, Two-tailed $p$ values are

736 shown in the Figure; Geometric mean with geometric standard deviation. 


\section{Supplementary figures}

A

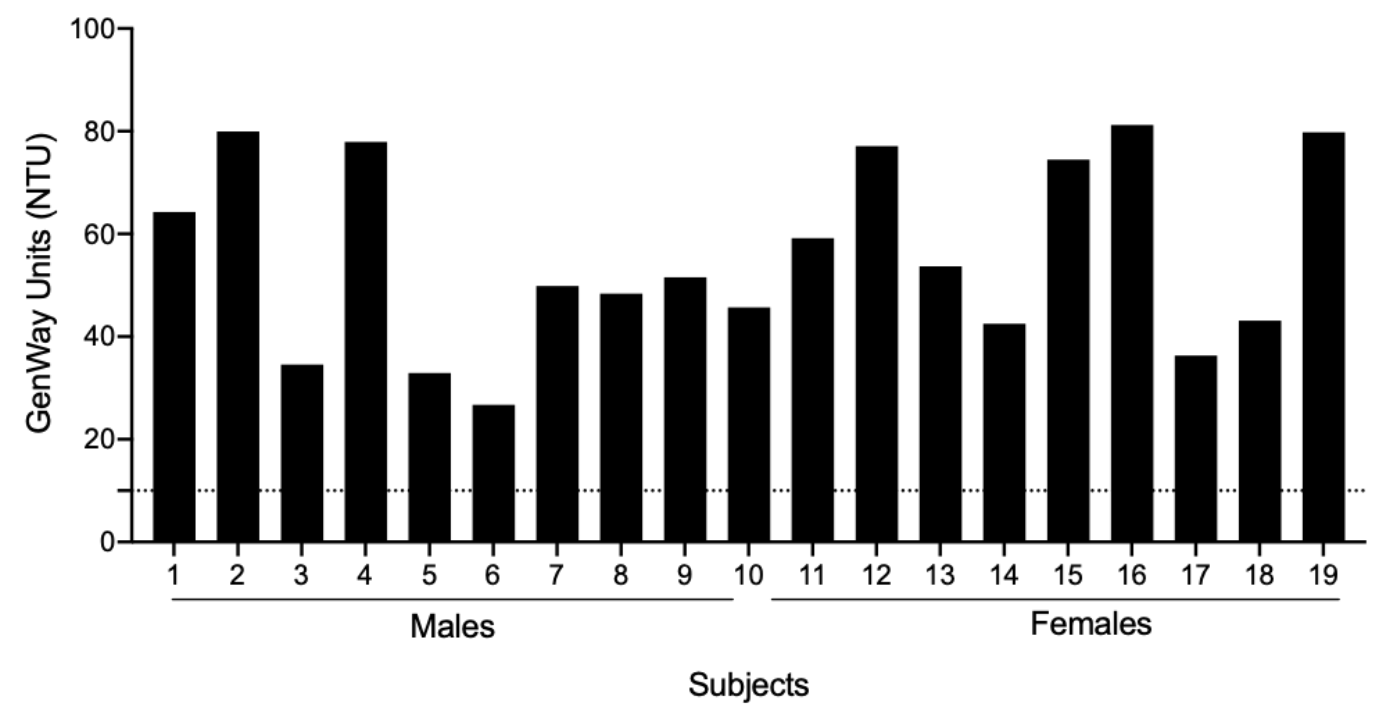

B

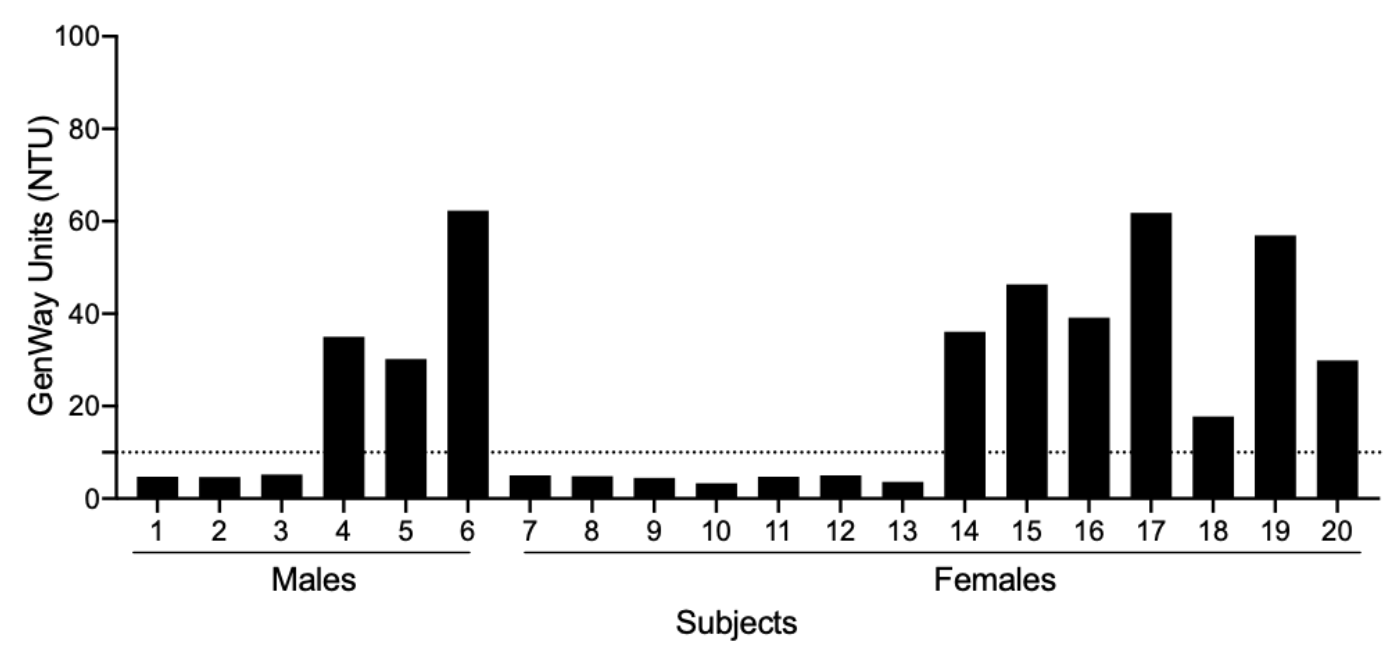

Fig. S1 Confirmation of HCMV seropositivity in donors. (A) IgG levels in plasma of

745 subjects in the screening cohort ( $n=10$ males, $n=9$ females) and $(B)$ the validation

746 cohort ( $n=13$ males, $n=26$ females) determined by ELISA. Dotted line represents the cut

747 off for positivity (10 NTU). 


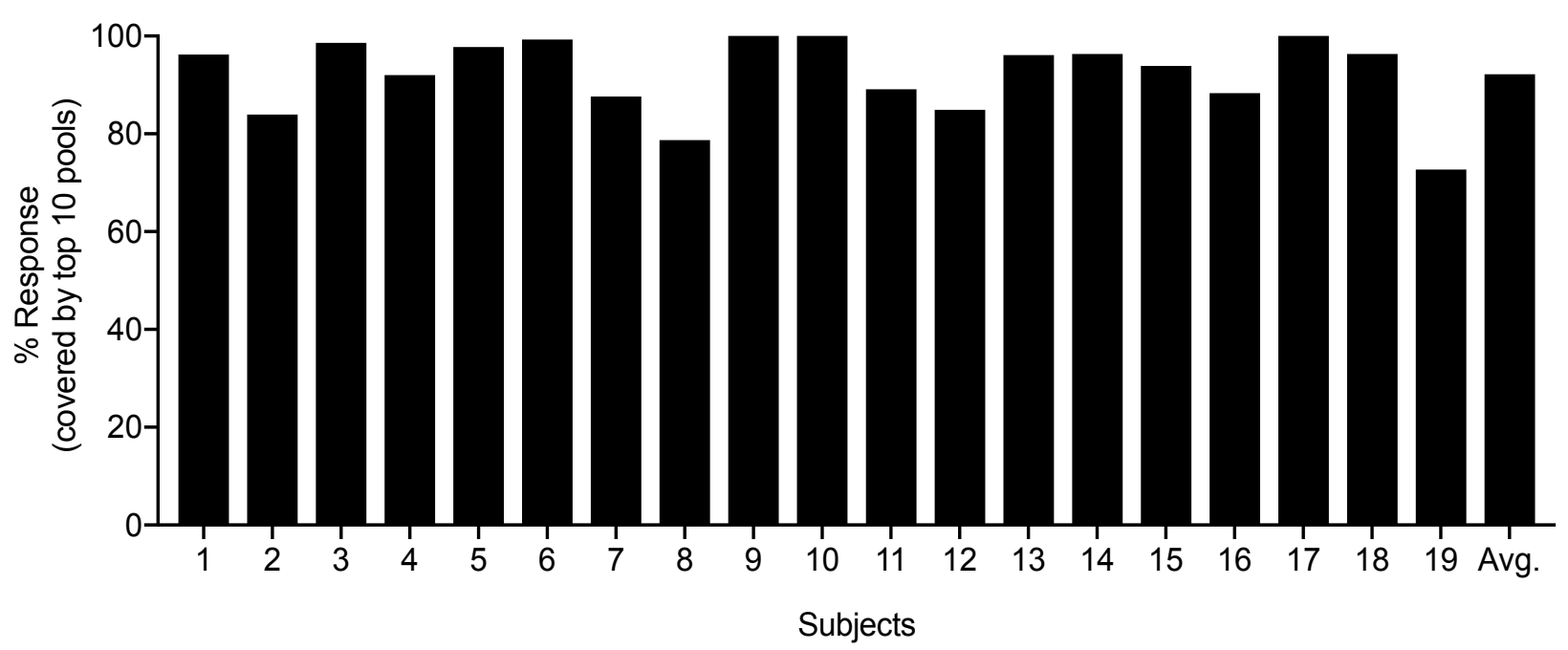

Fig. S2 The total T cell response captured by the top 10 epitope pools in each

750 subject. The response magnitude of the top 10 pools as a percentage of the total

751 response magnitude observed from all positive pools. On average, the top 10 pools

752 accounted for $\sim 90 \%$ of each subject's total response. 
IFN $\gamma$

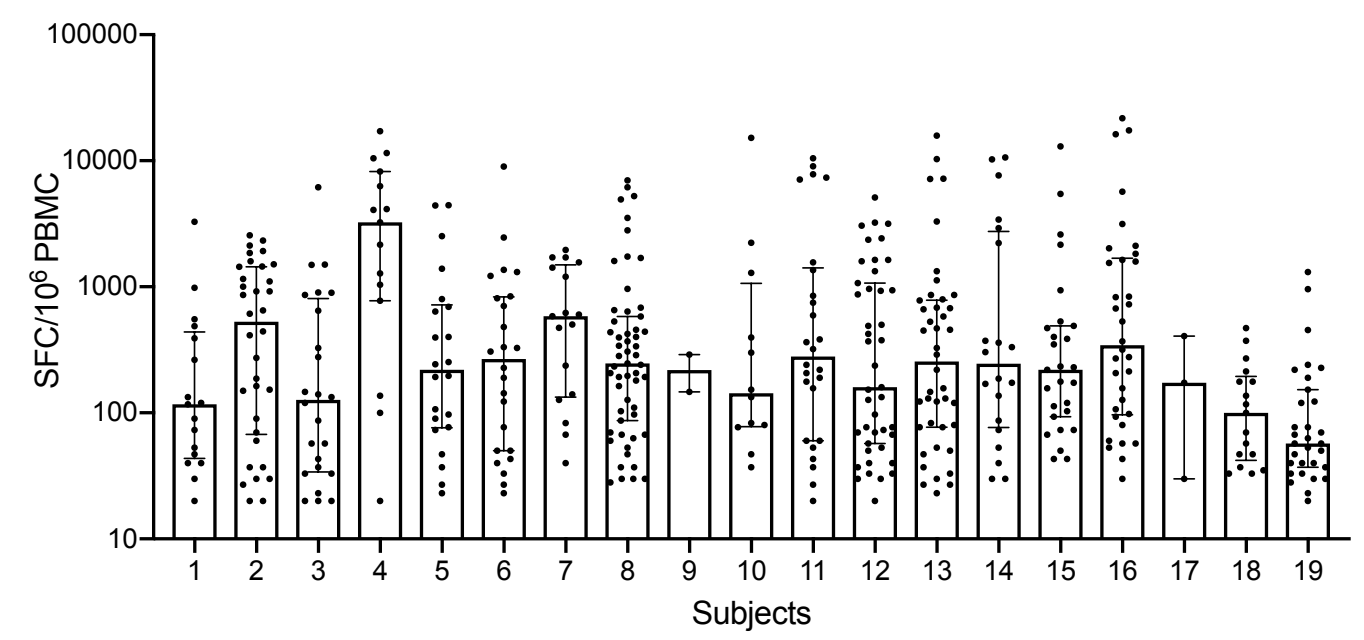

760 Fig. S3 Response magnitude of each epitope identified in HCMV seropositive

761 individuals: Each dot represents an epitope. $Y$ axis represents the response magnitude

762 of individual epitopes. $X$ axis represents each subject. Median \pm interquartile range is

763 shown.
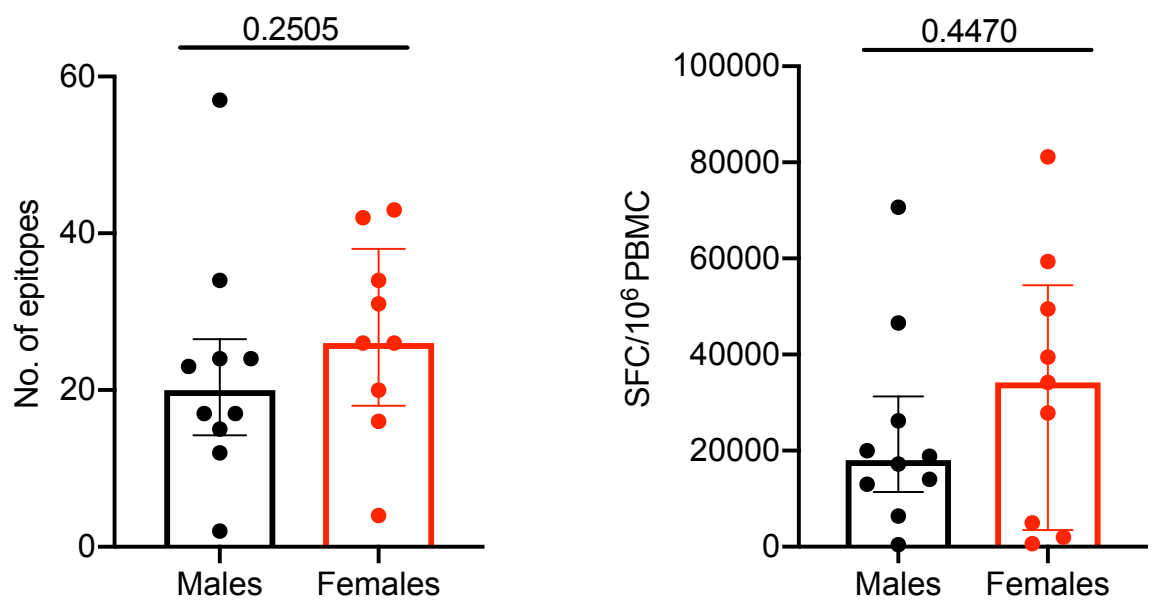

765 Fig. S4 Frequency and magnitude of response in males and females: Each dot

766 represents a donor. Black dot/bar represents males and red dot/bar represents females.

767 Median with interquartile range is displayed. Two-tailed Mann-Whitney test. 
A
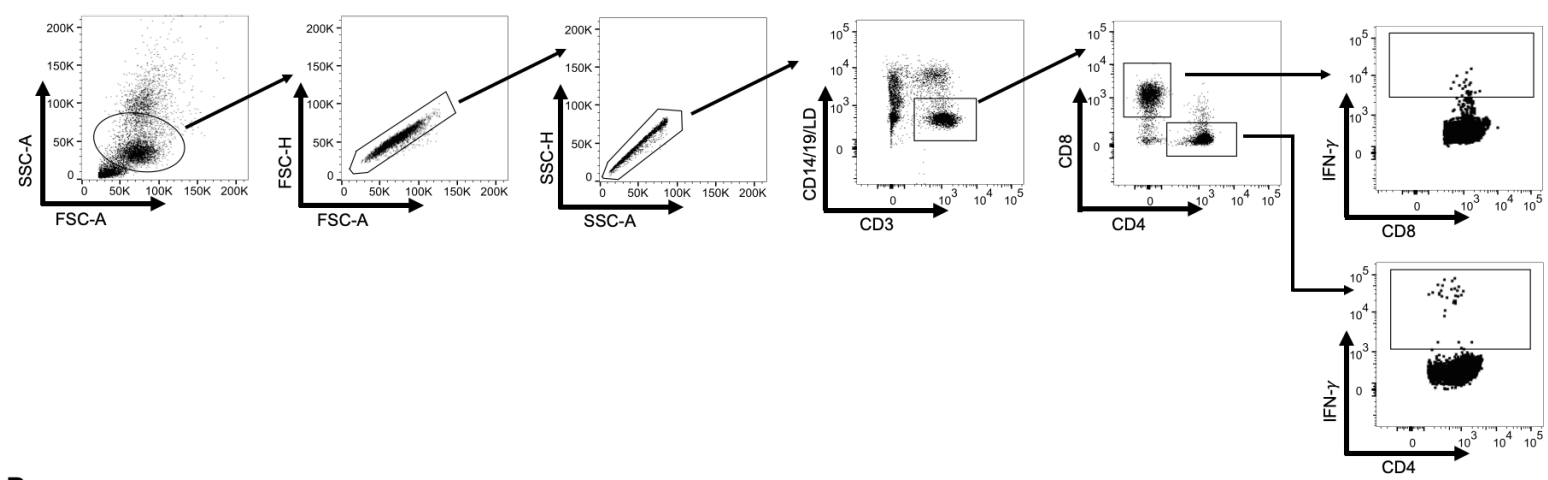

B
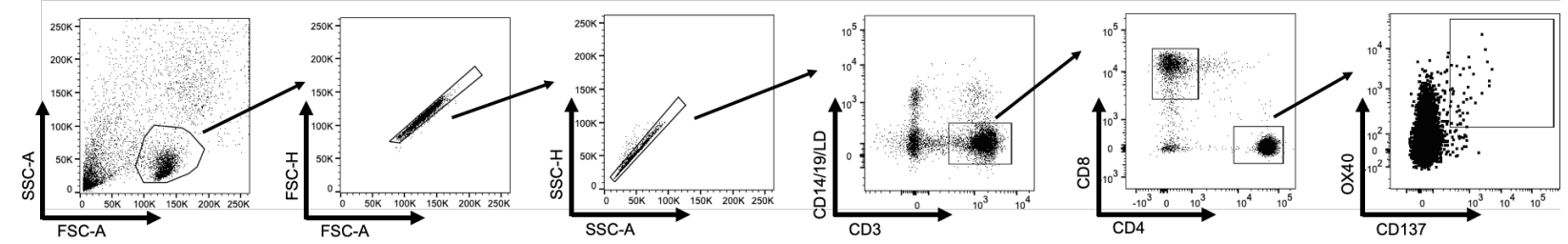

Fig. S5 Gating strategy adopted in IFN- $\gamma$ Fluorospot and AIM assay: (A) Human

771 PBMCs isolated from HCMV+ subjects were stimulated with each scoring peptide to

772 identify HCMV-specific IFN- $\gamma$ producing CD4+ and CD8+ T cells. (B) Human PBMCs

773 isolated from HCMV+ and HCMV- subjects were stimulated with each megapool

774 generated to identify HCMV-specific activation-induced marker assay positive (OX40+

775 CD137+) CD4+ T cells. 
783 Table 1: Details of HCMV specific 235 epitopes identified in the screen.

\begin{tabular}{|c|c|c|c|c|c|}
\hline S. No & Peptide sequence & $\begin{array}{l}\text { Peptide } \\
\text { length }\end{array}$ & ORF(s) & $\begin{array}{l}\text { No. of } \\
\text { subjects } \\
\text { responding }\end{array}$ & $\begin{array}{l}\text { Magnitude } \\
\text { of } \\
\text { response }\end{array}$ \\
\hline 1 & NGIRWQYQELQYLVE & 15 & $\begin{array}{c}\text { ORFL46W, } \\
\text { ORFL46W.iORF1_(UL13), } \\
\text { ORFL46W.iORF2 }\end{array}$ & 2 & 222 \\
\hline 2 & RYNALTVRSRDSLLL & 15 & $\begin{array}{c}\text { ORFL46W, } \\
\text { ORFL46W.iORF1_(UL13), } \\
\text { ORFL46W.iORF2 }\end{array}$ & 2 & 204 \\
\hline 3 & RVRTWFVQRTTLWRR & 15 & $\begin{array}{c}\text { ORFL46W, } \\
\text { ORFL46W.iORF1_(UL13), } \\
\text { ORFL46W.iORF2 }\end{array}$ & 1 & 60 \\
\hline 4 & GLWVSSYLVRRPMTI & 15 & $\begin{array}{c}\text { ORFL46W, } \\
\text { ORFL46W.iORF1_(UL13), } \\
\text { ORFL46W.iORF2 }\end{array}$ & 2 & 890 \\
\hline 5 & QGATYQLSIVRQAMQ & 15 & ORFL46W.iORF1_(UL13) & 1 & 650 \\
\hline 6 & GAGLRQLRQQLTVRW & 15 & ORFL46W.iORF2 & 1 & 20 \\
\hline 7 & MRTVPVTKLYTSRMV & 15 & ORFL49W_(UL16)(UL16P?) & 1 & 5677 \\
\hline 8 & AITLFFFLLALRIPQ & 15 & ORFL49W.iORF1 & 1 & 207 \\
\hline 9 & ALFTHFVGRPRHCRL & 15 & ORFL50W_(UL17) & 1 & 57 \\
\hline 10 & MLGIRAMLVMLDYYW & 15 & ORFL53W_(UL20) & 1 & 350 \\
\hline 11 & PSVRMDFRARRPLRR & 15 & ORFL55C_(UL21A) & 3 & 1740 \\
\hline 12 & ARRLWILSLLAVTLT & 15 & $\begin{array}{c}\text { ORFL57W_(UL22A), } \\
\text { ORFL57W.iORF1 }\end{array}$ & 1 & 100 \\
\hline 13 & LLAVTLTVALAAPSQ & 15 & ORFL57W_(UL22A) & 2 & 6420 \\
\hline 14 & KDRCLVIRRRWRLVR & 15 & ORFL64C_(UL23) & 1 & 60 \\
\hline
\end{tabular}




\begin{tabular}{|c|c|c|c|c|c|}
\hline 15 & FVAESITEFLNIGLR & 15 & ORFL64C_(UL23) & 1 & 530 \\
\hline 16 & HENGIYYGTRSMRKL & 15 & $\begin{array}{l}\text { ORFL64C_(UL23), } \\
\text { ORFL64C.iORF1 }\end{array}$ & 1 & 827 \\
\hline 17 & FCRRFFFPDRPDFFL & 15 & ORFL65C & 1 & 107 \\
\hline 18 & AEDSVFTSTRARSAT & 15 & ORFL70W_(UL25) & 1 & 490 \\
\hline 19 & KFVLQDFDVQHLRRL & 15 & ORFL70W_(UL25) & 1 & 40 \\
\hline 20 & IINYYYVAQKKARHM & 15 & ORFL70W_(UL25) & 1 & 163 \\
\hline 21 & ALALHFLTSRKGVTD & 15 & ORFL70W_(UL25) & 1 & 40 \\
\hline 22 & LMITHFQRTIRVLRC & 15 & ORFL70W_(UL25) & 3 & 2421 \\
\hline 23 & DFLRVVRQQDAFICT & 15 & ORFL70W_(UL25) & 2 & 174 \\
\hline 24 & ICVARLQAQPSSRHI & 15 & ORFL70W_(UL25) & 1 & 37 \\
\hline 25 & GVSSVTLLKIFSQVP & 15 & ORFL70W_(UL25) & 2 & 220 \\
\hline 26 & VLATLAAVRTRRRSV & 15 & $\begin{array}{c}\text { ORFL71C, ORFL71C.iORF1 } \\
\text { (UL24) }\end{array}$ & 2 & 340 \\
\hline 27 & EAYVRINAGQVLPVV & 15 & $\begin{array}{c}\text { ORFL71C, ORFL71C.iORF1 } \\
\text { (UL24) }\end{array}$ & 1 & 1853 \\
\hline 28 & LHCMRYLTSSLVKRY & 15 & ORFL71C & 1 & 150 \\
\hline 29 & KRYFRPLLRAWSLGL & 15 & $\begin{array}{c}\text { ORFL71C, ORFL71C.iORF1 } \\
\text { (UL24) }\end{array}$ & 4 & 1388 \\
\hline 30 & HLLRNIKTAFGMRVL & 15 & $\begin{array}{c}\text { ORFL71C, ORFL71C.iORF1 } \\
\text { (UL24) }\end{array}$ & 2 & 1093 \\
\hline 31 & ARNLMEFARVGLRAV & 15 & ORFL71C.iORF1 (UL24) & 1 & 1450 \\
\hline 32 & TGLVLLLLLLVVRLL & 15 & ORFL73C & 1 & 1440 \\
\hline 33 & MLFRPTISNSIPRCR & 15 & ORFL76C & 1 & 47 \\
\hline 34 & LRIIRLLRASIRHEY & 15 & ORFL79C_(UL27) & 1 & 810 \\
\hline 35 & RAHIQKFERLHVRRF & 15 & ORFL79C_(UL27) & 1 & 2523 \\
\hline 36 & SLQFIGLQRRDVVAL & 15 & ORFL92C_(UL32) & 1 & 83 \\
\hline
\end{tabular}




\begin{tabular}{|c|c|c|c|c|c|}
\hline 37 & RDVVALVNFLRHLTQ & 15 & ORFL92C_(UL32) & 1 & 1710 \\
\hline 38 & RRTVLFNELMLWLGY & 15 & ORFL92C_(UL32) & 1 & 180 \\
\hline 39 & VNAVNKLVYTGRLIM & 15 & ORFL92C_(UL32) & 1 & 340 \\
\hline 40 & KELRMCLSFDSNYCR & 15 & ORFL92C_(UL32) & 1 & 127 \\
\hline 41 & GMKTVAFDLSSPQKS & 15 & ORFL92C.iORF1 & 1 & 193 \\
\hline 42 & NAIVLITQLLTNRVL & 15 & ORFL93W_(UL33) & 1 & 37 \\
\hline 43 & STNFLTLTVLPFIVL & 15 & ORFL93W_(UL33) & 1 & 63 \\
\hline 44 & VLPFIVLSNQWLLPA & 15 & ORFL93W_(UL33) & 1 & 247 \\
\hline 45 & FATVALIAADRYRVL & 15 & ORFL93W_(UL33) & 4 & 2310 \\
\hline 46 & SYRSTYIILLLTWFA & 15 & ORFL93W_(UL33) & 3 & 3990 \\
\hline 47 & LTLRRTIGTLSRLVP & 15 & ORFL93W_(UL33) & 1 & 163 \\
\hline 48 & RRRMVSVTLFSPYSV & 15 & $\begin{array}{l}\text { ORFL98W.iORF1, } \\
\text { ORFL98W.iORF2 }\end{array}$ & 1 & 53 \\
\hline 49 & GRLMEVRQRNGRLRR & 15 & ORFL100C & 1 & 30 \\
\hline 50 & WPERCFIQLRSRSAL & 15 & $\begin{array}{c}\text { ORFL101C, } \\
\text { ORFL101C.iORF1_(UL36) }\end{array}$ & 3 & 313 \\
\hline 51 & GPGFMRYQLIVLIGQ & 15 & $\begin{array}{c}\text { ORFL101C, } \\
\text { ORFL101C.iORF1_(UL36) }\end{array}$ & 1 & 3167 \\
\hline 52 & IQTMELMIRTVPRIT & 15 & $\begin{array}{c}\text { ORFL101C, } \\
\text { ORFL101C.iORF1_(UL36) }\end{array}$ & 2 & 384 \\
\hline 53 & EFLVRQYVLVDTFGV & 15 & ORFL101C & 2 & 104 \\
\hline 54 & RREAIVRLEKTPTCQ & 15 & $\begin{array}{c}\text { ORFL101C, } \\
\text { ORFL101C.iORF1_(UL36) }\end{array}$ & 2 & 407 \\
\hline 55 & RRRFKVCDVGRRHII & 15 & $\begin{array}{c}\text { ORFL101C, } \\
\text { ORFL101C.iORF1_(UL36) }\end{array}$ & 1 & 63 \\
\hline 56 & RHRFLWQRRRRARLL & 15 & $\begin{array}{l}\text { ORFL103C_(vMIA), } \\
\text { ORFL104C_(UL37) }\end{array}$ & 1 & 1000 \\
\hline
\end{tabular}




\begin{tabular}{|c|c|c|c|c|c|}
\hline 57 & GSFSSFYSQIARSLG & 15 & ORFL105C_(UL40) & 1 & 363 \\
\hline 58 & FLKKMLLCALKGRAS & 15 & $\begin{array}{l}\text { ORFL115C_(UL45), } \\
\text { ORFL115C.iORF1 }\end{array}$ & 1 & 930 \\
\hline 59 & MPVQRLTVNVARCVF & 15 & ORFL115C_(UL45) & 1 & 20 \\
\hline 60 & KFIFELYRLPRLSIA & 15 & ORFL115C_(UL45) & 1 & 173 \\
\hline 61 & ASKIKMLETRVTLAL & 15 & ORFL116W_(UL47) & 1 & 140 \\
\hline 62 & ATMLSKYTRMSSLFN & 15 & ORFL127C_(UL48A) & 2 & 650 \\
\hline 63 & AFKLDLLRMIAVSRT & 15 & ORFL127C_(UL48A) & 2 & 477 \\
\hline 64 & MLFFQRYAPAFVTGY & 15 & ORFL143C_(UL54) & 1 & 57 \\
\hline 65 & DLKYILTRLEYLYKV & 15 & ORFL143C_(UL54) & 1 & 30 \\
\hline 66 & DPSYVREHGVPIHAD & 15 & ORFL143C_(UL54) & 1 & 123 \\
\hline 67 & TDLIRFERNIVCTSM & 15 & ORFL145C_(UL55) & 3 & 273 \\
\hline 68 & EGIMVVYKRNIVAHT & 15 & ORFL145C_(UL55) & 1 & 637 \\
\hline 69 & HTFKVRVYQKVLTFR & 15 & ORFL145C_(UL55) & 1 & 423 \\
\hline 70 & YQKVLTFRRSYAYIH & 15 & ORFL145C_(UL55) & 1 & 40 \\
\hline 71 & RRSYAYIHTTYLLGS & 15 & ORFL145C_(UL55) & 5 & 2730 \\
\hline 72 & QLMPDDYSNTHSTRY & 15 & ORFL145C_(UL55) & 5 & 45517 \\
\hline 73 & NLNCMVTITTARSKY & 15 & ORFL145C_(UL55) & 2 & 4810 \\
\hline 74 & NADKFFIFPNYTIVS & 15 & ORFL145C_(UL55) & 4 & 5120 \\
\hline 75 & GLVVFWQGIKQKSLV & 15 & ORFL145C_(UL55) & 1 & 53 \\
\hline 76 & QLQFTYDTLRGYINR & 15 & ORFL145C_(UL55) & 3 & 2236 \\
\hline 77 & LRGYINRALAQIAEA & 15 & ORFL145C_(UL55) & 3 & 30337 \\
\hline 78 & KELSKINPSAILSAI & 15 & ORFL145C_(UL55) & 3 & 18557 \\
\hline 79 & AILSAIYNKPIAARF & 15 & ORFL145C_(UL55) & 5 & 11264 \\
\hline 80 & ASCVTINQTSVKVLR & 15 & ORFL145C_(UL55) & 5 & 8941 \\
\hline 81 & YLFKRMIDLSSISTV & 15 & ORFL145C_(UL55) & 1 & 67 \\
\hline 82 & EQAYQMLLALARLDA & 15 & ORFL145C_(UL55) & 4 & 21807 \\
\hline
\end{tabular}




\begin{tabular}{|c|c|c|c|c|c|}
\hline 83 & LLDRLRHRKNGYRHL & 15 & ORFL145C.iORF1 & 3 & 12544 \\
\hline 84 & QILWTDGLARRTRDR & 15 & ORFL145C.iORF2 & 1 & 37 \\
\hline 85 & RVGITIQQLNVYHQL & 15 & ORFL146C_(UL56) & 1 & 963 \\
\hline 86 & TMRSVFEMQRIRHGA & 15 & ORFL147C & 1 & 67 \\
\hline 87 & NIFLVGFYLLVPYLG & 15 & ORFL147C & 1 & 1633 \\
\hline 88 & SLLILVVLLLIYRCC & 15 & ORFL159W & 1 & 23 \\
\hline 89 & LSYMKYHHLHGLPVN & 15 & ORFL161C_(UL69) & 3 & 879 \\
\hline 90 & VELCLGAGAGHVVVV & 15 & ORFL162W & 1 & 383 \\
\hline 91 & RSSWRASCVEVPKKP & 15 & ORFL165W & 1 & 370 \\
\hline 92 & MQKYFSLDNFLHDYV & 15 & UL70 & 2 & 20343 \\
\hline 93 & QTIYFLGLTALLLRY & 15 & ORFL181C_(UL74) & 1 & 583 \\
\hline 94 & SFYLVNAMSRNLFRV & 15 & ORFL181C_(UL74) & 1 & 43 \\
\hline 95 & TMRKLKRKQALVKEQ & 15 & ORFL181C_(UL74) & 1 & 1563 \\
\hline 96 & TAVSEFMKNTHVLIR & 15 & ORFL181C.iORF1 & 1 & 747 \\
\hline 97 & WREDVLMDRVRKRYL & 15 & ORFL189W_(UL77) & 1 & 67 \\
\hline 98 & IKMWFLLGAPMIAVL & 15 & $\begin{array}{l}\text { ORFL196W_(UL78), } \\
\text { ORFL196W.iORF1 }\end{array}$ & 3 & 2867 \\
\hline 99 & LFIIAFFSREPTKDL & 15 & ORFL196W_(UL78) & 1 & 190 \\
\hline 100 & PKSFTLTRIHPEYIV & 15 & ORFL202C_(UL82/pp71) & 2 & 340 \\
\hline 101 & PEYIVQIQNAFETNQ & 15 & ORFL202C_(UL82/pp71) & 4 & 527 \\
\hline 102 & GALTLVIPSWHVFAS & 15 & ORFL202C_(UL82/pp71) & 2 & 190 \\
\hline 103 & CRSATSLVGNTNADV & 15 & ORFL203W & 1 & 30 \\
\hline 104 & SSCAHTTCRSATSLV & 15 & ORFL203W & 2 & 104 \\
\hline 105 & SWLGQMLRPVGLCTL & 15 & ORFL204W & 1 & 43 \\
\hline 106 & QTGIHVRVSQPSLIL & 15 & $\begin{array}{c}\text { ORFL205C_(UL83/pp65), } \\
\text { ORFL205C.iORF1 }\end{array}$ & 11 & 33563 \\
\hline 107 & MSIYVYALPLKMLNI & 15 & ORFL205C_(UL83/pp65) & 1 & 83 \\
\hline
\end{tabular}




\begin{tabular}{|c|c|c|c|c|c|}
\hline 108 & PLKMLNIPSINVHHY & 15 & ORFL205C_(UL83/pp65) & 7 & 2920 \\
\hline 109 & ATKMQVIGDQYVKVY & 15 & $\begin{array}{c}\text { ORFL205C_(UL83/pp65), } \\
\text { ORFL205C.iORF1 }\end{array}$ & 2 & 4637 \\
\hline 110 & PKNMIIKPGKISHIM & 15 & $\begin{array}{c}\text { ORFL205C_(UL83/pp65), } \\
\text { ORFL205C.iORF1 }\end{array}$ & 5 & 538 \\
\hline 111 & PGKISHIMLDVAFTS & 15 & $\begin{array}{c}\text { ORFL205C_(UL83/pp65), } \\
\text { ORFL205C.iORF1 }\end{array}$ & 9 & 2386 \\
\hline 112 & MNGQQIFLEVQAIRE & 15 & $\begin{array}{c}\text { ORFL205C_(UL83/pp65), } \\
\text { ORFL205C.iORF1 }\end{array}$ & 6 & 3990 \\
\hline 113 & ELRQYDPVAALFFFD & 15 & ORFL205C_(UL83/pp65) & 8 & 1106 \\
\hline 114 & GILARNLVPMVATVQ & 15 & $\begin{array}{c}\text { ORFL205C_(UL83/pp65), } \\
\text { ORFL205C.iORF1 }\end{array}$ & 11 & 34633 \\
\hline 115 & ALFFFDIDLLLQRGP & 15 & ORFL205C.iORF1 & 2 & 73 \\
\hline 116 & RVTGLVFSVVFSVSL & 15 & ORFL206W & 4 & 6380 \\
\hline 117 & LTWCVIADRQPRFSV & 15 & ORFL206W & 3 & 240 \\
\hline 118 & RPKRRVVAPFRVAAA & 15 & ORFL207W & 2 & 283 \\
\hline 119 & APFRVAAAGETPLGR & 15 & ORFL207W & 6 & 1089 \\
\hline 120 & IPQRLHLIKHYQLGL & 15 & ORFL209C_(UL85) & 1 & 437 \\
\hline 121 & IVPMPLALEINQRLL & 15 & ORFL209C_(UL85) & 1 & 283 \\
\hline 122 & LASELTMTYVRKLAL & 15 & ORFL209C_(UL85) & 1 & 37 \\
\hline 123 & HSILADFNSYKAHLT & 15 & $\begin{array}{c}\text { ORFL212C_(UL86) Major } \\
\text { Capsid Protein }\end{array}$ & 1 & 27 \\
\hline 124 & FHELRTWEIMEHMRL & 15 & $\begin{array}{c}\text { ORFL212C_(UL86) Major } \\
\text { Capsid Protein }\end{array}$ & 1 & 7343 \\
\hline 125 & PQLLFHYRNLVAVLR & 15 & $\begin{array}{c}\text { ORFL212C_(UL86) Major } \\
\text { Capsid Protein }\end{array}$ & 1 & 60 \\
\hline
\end{tabular}




\begin{tabular}{|c|c|c|c|c|c|}
\hline 126 & RNLVAVLRLVTRISA & 15 & $\begin{array}{c}\text { ORFL212C_(UL86) Major } \\
\text { Capsid Protein }\end{array}$ & 1 & 20 \\
\hline 127 & LFLAVQFVGEHVKVL & 15 & $\begin{array}{c}\text { ORFL212C_(UL86) Major } \\
\text { Capsid Protein }\end{array}$ & 1 & 53 \\
\hline 128 & VRVQDLFRVFPMNVY & 15 & $\begin{array}{c}\text { ORFL212C_(UL86) Major } \\
\text { Capsid Protein }\end{array}$ & 1 & 43 \\
\hline 129 & LGYNSKFYSPCAQYF & 15 & $\begin{array}{c}\text { ORFL212C_(UL86) Major } \\
\text { Capsid Protein }\end{array}$ & 1 & 20 \\
\hline 130 & TQEALPILSTTTLAL & 15 & $\begin{array}{c}\text { ORFL212C_(UL86) Major } \\
\text { Capsid Protein }\end{array}$ & 1 & 407 \\
\hline 131 & PFTVLRLSYAYRIFA & 15 & ORFL229W_(UL98) & 1 & 33 \\
\hline 132 & AREFLLSHDAALFRA & 15 & ORFL229W_(UL98) & 1 & 23 \\
\hline 133 & MLIQQYVLSQYYIKK & 15 & ORFL229W_(UL98) & 1 & 20 \\
\hline 134 & RLGTAATQIQKQTLY & 15 & ORFL233C & 1 & 30 \\
\hline 135 & KTQIFNKLFTNRISV & 15 & ORFL236C & 1 & 1587 \\
\hline 136 & VRSLAVDAQHAAKRV & 15 & ORFL238W & 1 & 53 \\
\hline 137 & LEERDEWVRSLAVDA & 15 & ORFL238W & 1 & 47 \\
\hline 138 & AAITVVPVITQSRLA & 15 & ORFL245C & 3 & 450 \\
\hline 139 & PWYPITQARTLELTP & 15 & ORFL246C & 2 & 996 \\
\hline 140 & MSTKRSTVPWYPITQ & 15 & ORFL246C & 3 & 477 \\
\hline 141 & LRVTFHRVKPTLQRE & 15 & ORFL248W.iORF1 & 2 & 830 \\
\hline 142 & SGRVILWTTLRLCIL & 15 & ORFL249C & 1 & 20 \\
\hline 143 & VVRKYWTFTNPNRIL & 15 & $\begin{array}{c}\text { ORFL251W, ORFL252W, } \\
\text { ORFL253W_(UL112), } \\
\text { ORFL253W.iORF1, } \\
\text { ORFL253W.iORF2 }\end{array}$ & 3 & 16876 \\
\hline
\end{tabular}




\begin{tabular}{|c|c|c|c|c|c|}
\hline 144 & TFDVRQFVFDNARLV & 15 & $\begin{array}{c}\text { ORFL251W, ORFL252W, } \\
\text { ORFL253W_(UL112), } \\
\text { ORFL253W.iORF1, } \\
\text { ORFL253W.iORF2 }\end{array}$ & 6 & 13736 \\
\hline 145 & VRGGIVFNKSVSSVV & 15 & $\begin{array}{c}\text { ORFL251W, ORFL252W, } \\
\text { ORFL253W_(UL112), } \\
\text { ORFL253W.iORF1, } \\
\text { ORFL253W.iORF2 }\end{array}$ & 5 & 2691 \\
\hline 146 & GNLQVTYVRHYLKNH & 15 & $\begin{array}{c}\text { ORFL253W_(UL112), } \\
\text { ORFL253W.iORF1, } \\
\text { ORFL253W.iORF2 }\end{array}$ & 4 & 655 \\
\hline 147 & AVAFLNYSSSSSAVS & 15 & $\begin{array}{c}\text { ORFL253W_(UL112), } \\
\text { ORFL253W.iORF1, } \\
\text { ORFL253W.iORF2 }\end{array}$ & 3 & 2151 \\
\hline 148 & AGLMMMRRMRRAPAE & 15 & ORFL253W_(UL112) & 1 & 490 \\
\hline 149 & CDLPLVSSRLLPETS & 15 & ORFL253W_(UL112) & 1 & 123 \\
\hline 150 & CEIKPYVVNPVVATA & 15 & ORFL253W_(UL112) & 3 & 2583 \\
\hline 151 & DPLLRLSQVAGSGRR & 15 & ORFL253W_(UL112) & 2 & 2067 \\
\hline 152 & LPLCSTARLRLAPRR & 15 & ORFL253W.iORF3 & 1 & 467 \\
\hline 153 & RATGNFRSTSLYAAV & 15 & ORFL253W.iORF3 & 3 & 4220 \\
\hline 154 & RCCTLRFRRRCRARC & 15 & ORFL253W.iORF4 & 2 & 713 \\
\hline 155 & MSATRHHRCCTLRFR & 15 & ORFL253W.iORF4 & 1 & 277 \\
\hline 156 & RVFCLSADWIRFLSL & 15 & ORFL254C_(UL114) & 2 & 846 \\
\hline 157 & HLGWQTLSNHVIRRL & 15 & ORFL254C_(UL114) & 1 & 127 \\
\hline 158 & TVVRLHVQIAGRSFT & 15 & ORFL258C_(UL119) & 1 & 213 \\
\hline 159 & SCTHPYVISLVTPLT & 15 & ORFL260C_(UL121) & 1 & 80 \\
\hline 160 & ISLVTPLTINATLRL & 15 & ORFL260C_(UL121) & 1 & 317 \\
\hline
\end{tabular}




\begin{tabular}{|c|c|c|c|c|c|}
\hline 161 & CRVDADLGLLYAVCL & 15 & ORFL260C_(UL121) & 1 & 673 \\
\hline 162 & VCLILSFSIVTAALW & 15 & ORFL260C_(UL121) & 1 & 43 \\
\hline 163 & MFFLAIRDHDTAGGI & 15 & ORFL261W & 1 & 1637 \\
\hline 164 & LQTMLRKEVNSQLSL & 15 & $\begin{array}{l}\text { ORFL264C_(UL123) IE1, } \\
\text { ORFL265C_(UL122) IE2 }\end{array}$ & 2 & 1606 \\
\hline 165 & LVKQIKVRVDMVRHR & 15 & ORFL264C_(UL123) IE1 & 3 & 580 \\
\hline 166 & RVDMVRHRIKEHMLK & 15 & ORFL264C_(UL123) IE1 & 2 & 250 \\
\hline 167 & LRRKMMYMCYRNIEF & 15 & ORFL264C_(UL123) IE1 & 6 & 1697 \\
\hline 168 & CSPDEIMSYAQKIFK & 15 & ORFL264C_(UL123) IE1 & 2 & 194 \\
\hline 169 & EERDKVLTHIDHIFM & 15 & ORFL264C_(UL123) IE1 & 2 & 107 \\
\hline 170 & VLCCYVLEETSVMLA & 15 & ORFL264C_(UL123) IE1 & 1 & 93 \\
\hline 171 & ITKPEVISVMKRRIE & 15 & ORFL264C_(UL123) IE1 & 1 & 1600 \\
\hline 172 & FAQYILGADPLRVCS & 15 & ORFL264C_(UL123) IE1 & 1 & 30 \\
\hline 173 & EAIVAYTLATAGASS & 15 & ORFL264C_(UL123) IE1 & 3 & 19333 \\
\hline 174 & TTRPFKVIIKPPVPP & 15 & ORFL265C_(UL122) IE2 & 2 & 424 \\
\hline 175 & NKGIQIIYTRNHEVK & 15 & $\begin{array}{c}\text { ORFL265C_(UL122) IE2, } \\
\text { ORFL265C.iORF1, } \\
\text { ORFL265C.iORF2, } \\
\text { ORFL265C.iORF3, }\end{array}$ & 7 & 3794 \\
\hline 176 & LGSMCNLALSTPFLM & 15 & $\begin{array}{c}\text { ORFL265C_(UL122) IE2, } \\
\text { ORFL265C.iORF1, } \\
\text { ORFL265C.iORF2 }\end{array}$ & 4 & 668 \\
\hline 177 & STPFLMEHTMPVTHP & 15 & $\begin{array}{c}\text { ORFL265C_(UL122) IE2, } \\
\text { ORFL265C.iORF1, } \\
\text { ORFL265C.iORF2, } \\
\text { ORFL265C.iORF3, }\end{array}$ & 4 & 740 \\
\hline 178 & YRNMIIHAATPVDLL & 15 & ORFL265C.iORF3 & 2 & 130 \\
\hline
\end{tabular}




\begin{tabular}{|c|c|c|c|c|c|}
\hline 179 & VMVRIFSTNQGGFML & 15 & ORFL265C.iORF3 & 2 & 3560 \\
\hline 180 & VVVGIVLCLSLASTV & 15 & ORFL266W_(UL124) & 1 & 1417 \\
\hline 181 & SPVAAELPHPSPAPM & 15 & ORFL267C & 2 & 166 \\
\hline 182 & SYLAVHLRISHRYYH & 15 & ORFL269C & 1 & 290 \\
\hline 183 & IAITMVMRFWQYING & 15 & ORFL270C & 3 & 163 \\
\hline 184 & TALWLLLGHSRVPRV & 15 & UL128 & 1 & 177 \\
\hline 185 & AEIRGIVTTMTHSLT & 15 & ORFL271C_(UL128_truncated) & 1 & 1713 \\
\hline 186 & NPLYLEADGRIRCGK & 15 & $\begin{array}{c}\text { ORFL271C_(UL128_truncated), } \\
\text { UL128 }\end{array}$ & 2 & 884 \\
\hline 187 & LHRRAAVSGRRSLLQ & 15 & ORFL271C.iORF1 & 1 & 87 \\
\hline 188 & MLRLLFTLVLLALYG & 15 & ORFL278C_(UL148) & 3 & 4593 \\
\hline 189 & HVRLLSYRGDPLVFK & 15 & ORFL278C_(UL148) & 3 & 333 \\
\hline 190 & VVRFALYLETLSRIV & 15 & ORFL278C_(UL148) & 2 & 123 \\
\hline 191 & FYMNWTLRRSQTHYL & 15 & ORFL278C_(UL148) & 6 & 16883 \\
\hline 192 & QVEILKPRGVRHRAI & 15 & ORFL278C_(UL148) & 9 & 3468 \\
\hline 193 & FCVYRYNARLTRGYV & 15 & ORFL278C_(UL148) & 3 & 700 \\
\hline 194 & TRGYVRYTLSPKARL & 15 & ORFL278C_(UL148) & 7 & 9337 \\
\hline 195 & SLDRFIVQYLNTLLI & 15 & ORFL278C_(UL148) & 8 & 23368 \\
\hline 196 & PTWSTTVNAHNSFLH & 15 & ORFL278C.iORF1 & 1 & 47 \\
\hline 197 & DRLSTLAATMCMFDY & 15 & ORFL279C & 1 & 53 \\
\hline 198 & LFYRAVALGTLSALV & 15 & ORFL280C_(UL147A) & 3 & 2633 \\
\hline 199 & SSIFTSTHRGVIVAP & 15 & ORFL283W & 1 & 27 \\
\hline 200 & LSVRYLSLTAYMLLA & 15 & ORFL284C_(UL147) & 1 & 1200 \\
\hline 201 & TAYKAFLWKYAKKLN & 15 & ORFL284C_(UL147) & 1 & 503 \\
\hline 202 & WKYAKKLNYHYFRLR & 15 & ORFL284C_(UL147) & 1 & 237 \\
\hline 203 & VYLWYVRRQLVAFCL & 15 & ORFL318C_(UL148A) & 3 & 253 \\
\hline 204 & FPSARDIPKQLPEQP & 15 & ORFL320W & 1 & 27 \\
\hline
\end{tabular}




\begin{tabular}{|c|c|c|c|c|c|}
\hline 205 & VVAYVILERLWLAAR & 15 & ORFL321W.iORF1 & 1 & 23 \\
\hline 206 & IRRWWISVAIVIFIG & 15 & $\begin{array}{c}\text { ORFL321W.iORF2, } \\
\text { ORFL321W.iORF3_(UL148D) }\end{array}$ & 3 & 10480 \\
\hline 207 & RWQFAVCAASKTATR & 15 & ORFL322W & 1 & 50 \\
\hline 208 & PQRLLLTALAIWQRT & 15 & ORFL324C_(UL150) & 1 & 983 \\
\hline 209 & PWWRRLRVKRPKFPS & 15 & $\begin{array}{c}\text { ORFS326C } \\
\text { ORFS326C.iORF1_(US1) }\end{array}$ & 1 & 240 \\
\hline 210 & LWYLGDYGAILKIYF & 15 & ORFS337C_(US10) & 1 & 40 \\
\hline 211 & LFCGACVITRSLLLI & 15 & ORFS337C_(US10) & 1 & 487 \\
\hline 212 & MNLVMLILALWAPVA & 15 & ORFS338C_(US11) & 1 & 553 \\
\hline 213 & VSEYRVEYSEARCVL & 15 & ORFS338C_(US11) & 1 & 263 \\
\hline 214 & MLVVTVFDTTRLFEI & 15 & ORFS345C_(US17) & 1 & 840 \\
\hline 215 & VCAFCWLVLPHRLEQ & 15 & ORFS351C_(US21) & 1 & 1960 \\
\hline 216 & VSVLYFMPSEPGSAH & 15 & ORFS351C.iORF2 & 1 & 177 \\
\hline 217 & VFQKTLSMLQGLYLR & 15 & ORFS352C_(US22) & 2 & 327 \\
\hline 218 & GLYLRQYDPPALRTY & 15 & ORFS352C_(US22) & 2 & 633 \\
\hline 219 & WFLVMREQAAIPQIY & 15 & ORFS352C_(US22) & 4 & 1100 \\
\hline 220 & QIYARSLAADYLCCD & 15 & ORFS352C_(US22) & 1 & 33 \\
\hline 221 & DFRDLLNFIRQRLCC & 15 & ORFS352C_(US22) & 1 & 30 \\
\hline 222 & PSQEILLLCARHLDE & 15 & ORFS353C_(US23) & 3 & 110 \\
\hline 223 & TDCWPFEVAPAARLA & 15 & ORFS353C_(US23) & 2 & 1637 \\
\hline 224 & LFRAGLMKVYVRRRY & 15 & ORFS353C_(US23) & 1 & 870 \\
\hline 225 & VVFMGRFSRVYAYDT & 15 & ORFS355C_(US24) & 1 & 70 \\
\hline 226 & EKYMVLVSHNLDELA & 15 & ORFS355C_(US24) & 1 & 20 \\
\hline 227 & PRLHCLVTTRSSTRE & 15 & ORFS355C.iORF1 & 1 & 1277 \\
\hline 228 & LRYKWLIRKDRFIVR & 15 & ORFS361C_(US26) & 1 & 3247 \\
\hline 229 & TNIMLQVSNVTNHTL & 15 & ORFS363W_(US27) & 1 & 58 \\
\hline
\end{tabular}




\begin{tabular}{|c|c|c|c|c|c|}
\hline 230 & IVVGLPFFLEYAKHH & 15 & ORFS363W_(US27) & 2 & 1250 \\
\hline 231 & YNRMVRFIINYVGKW & 15 & ORFS363W_(US27) & 1 & 23 \\
\hline 232 & ITFCLYVGQFLAYVR & 15 & ORFS363W_(US27) & 1 & 27 \\
\hline 233 & HDPLGLTRFIMRQLM & 15 & ORFS370W_(US33A) & 1 & 473 \\
\hline 234 & FIMRQLMMYPLVLPF & 15 & ORFS370W_(US33A) & 1 & 530 \\
\hline 235 & GLVYRELHDFYGYLQ & 15 & ORFS371W_(US34) & 1 & 963 \\
\hline
\end{tabular}

784

785

786

787

788

789

790

791

792

793

794

795

796

797

798

799

800

801 


\section{Table 2: Details of HCMV specific class II epitopes from IEDB}

\begin{tabular}{|c|c|c|c|c|}
\hline S. No & Peptide sequence & $\begin{array}{l}\text { Peptide } \\
\text { length }\end{array}$ & ORF & Antigen Name from IEDB \\
\hline 1 & HINSHSQCYSSYSRVIA & 17 & ORFL145C_(UL55) & glycoprotein B \\
\hline 2 & SRVIAGTVFVAYHRD & 15 & ORFL145C_(UL55) & glycoprotein B \\
\hline 3 & CMVTITTARSKYPYH & 15 & ORFL145C_(UL55) & glycoprotein B \\
\hline 4 & VFETTGGLVVFWQGI & 15 & ORFL145C_(UL55) & glycoprotein B \\
\hline 5 & MQLIPDDYSNTHSTRYVTVK & 20 & ORFL145C_(UL55) & glycoprotein B \\
\hline 6 & LPLKMLNIPSINVH & 14 & ORFL205C_(UL83/pp65) & $\begin{array}{c}65 \mathrm{kDa} \text { lower matrix } \\
\text { phosphoprotein }\end{array}$ \\
\hline 7 & PQYSEHPTFTSQYRIQ & 16 & ORFL205C_(UL83/pp65) & $\begin{array}{c}65 \mathrm{kDa} \text { lower matrix } \\
\text { phosphoprotein }\end{array}$ \\
\hline 8 & FTSQYRIQGKLEYRHT & 16 & ORFL205C_(UL83/pp65) & $\begin{array}{c}65 \mathrm{kDa} \text { lower matrix } \\
\text { phosphoprotein }\end{array}$ \\
\hline 9 & PPWQAGILARNLVPMV & 16 & ORFL205C_(UL83/pp65) & $\begin{array}{c}65 \mathrm{kDa} \text { lower matrix } \\
\text { phosphoprotein }\end{array}$ \\
\hline 10 & KYQEFFWDANDIYRIF & 16 & ORFL205C_(UL83/pp65) & $\begin{array}{c}65 \mathrm{kDa} \text { lower matrix } \\
\text { phosphoprotein }\end{array}$ \\
\hline 11 & GPISGHVLKAVFSRG & 15 & ORFL205C_(UL83/pp65) & $\begin{array}{c}65 \mathrm{kDa} \text { lower matrix } \\
\text { phosphoprotein }\end{array}$ \\
\hline 12 & LLQTGIHVRVSQPSL & 15 & ORFL205C_(UL83/pp65) & $\begin{array}{c}65 \mathrm{kDa} \text { lower matrix } \\
\text { phosphoprotein }\end{array}$ \\
\hline 13 & IYVYALPLKMLNIPS & 15 & ORFL205C_(UL83/pp65) & $\begin{array}{c}65 \mathrm{kDa} \text { lower matrix } \\
\text { phosphoprotein }\end{array}$ \\
\hline
\end{tabular}




\begin{tabular}{|c|c|c|c|c|}
\hline 14 & LPLKMLNIPSINVHH & 15 & ORFL205C_(UL83/pp65) & $\begin{array}{c}65 \mathrm{kDa} \text { lower matrix } \\
\text { phosphoprotein }\end{array}$ \\
\hline 15 & KDVALRHVVCAHELV & 15 & ORFL205C_(UL83/pp65) & $\begin{array}{c}65 \mathrm{kDa} \text { lower matrix } \\
\text { phosphoprotein }\end{array}$ \\
\hline 16 & RHVVCAHELVCSMEN & 15 & ORFL205C_(UL83/pp65) & $\begin{array}{c}65 \mathrm{kDa} \text { lower matrix } \\
\text { phosphoprotein }\end{array}$ \\
\hline 17 & CSMENTRATKMQVIG & 15 & ORFL205C_(UL83/pp65) & $\begin{array}{c}65 \mathrm{kDa} \text { lower matrix } \\
\text { phosphoprotein }\end{array}$ \\
\hline 18 & TRATKMQVIGDQYVK & 15 & ORFL205C_(UL83/pp65) & $\begin{array}{c}65 \mathrm{kDa} \text { lower matrix } \\
\text { phosphoprotein }\end{array}$ \\
\hline 19 & MQVIGDQYVKVYLES & 15 & ORFL205C_(UL83/pp65) & $\begin{array}{c}65 \mathrm{kDa} \text { lower matrix } \\
\text { phosphoprotein }\end{array}$ \\
\hline 20 & VYLESFCEDVPSGKL & 15 & ORFL205C_(UL83/pp65) & $\begin{array}{c}65 \mathrm{kDa} \text { lower matrix } \\
\text { phosphoprotein }\end{array}$ \\
\hline 21 & FCEDVPSGKLFMHVT & 15 & ORFL205C_(UL83/pp65) & $\begin{array}{c}65 \mathrm{kDa} \text { lower matrix } \\
\text { phosphoprotein }\end{array}$ \\
\hline 22 & LGSDVEEDLTMTRNP & 15 & ORFL205C_(UL83/pp65) & $\begin{array}{c}65 \mathrm{kDa} \text { lower matrix } \\
\text { phosphoprotein }\end{array}$ \\
\hline 23 & EEDLTMTRNPQPFMR & 15 & ORFL205C_(UL83/pp65) & $\begin{array}{c}65 \mathrm{kDa} \text { lower matrix } \\
\text { phosphoprotein }\end{array}$ \\
\hline 24 & QPFMRPHERNGFTVL & 15 & ORFL205C_(UL83/pp65) & $\begin{array}{c}65 \mathrm{kDa} \text { lower matrix } \\
\text { phosphoprotein }\end{array}$ \\
\hline 25 & KISHIMLDVAFTSHE & 15 & ORFL205C_(UL83/pp65) & $\begin{array}{c}65 \mathrm{kDa} \text { lower matrix } \\
\text { phosphoprotein }\end{array}$ \\
\hline 26 & MLDVAFTSHEHFGLL & 15 & ORFL205C_(UL83/pp65) & $\begin{array}{c}65 \mathrm{kDa} \text { lower matrix } \\
\text { phosphoprotein }\end{array}$ \\
\hline
\end{tabular}




\begin{tabular}{|c|c|c|c|c|}
\hline 27 & FTSHEHFGLLCPKSI & 15 & ORFL205C_(UL83/pp65) & $\begin{array}{c}65 \mathrm{kDa} \text { lower matrix } \\
\text { phosphoprotein }\end{array}$ \\
\hline 28 & PQYSEHPTFTSQYRI & 15 & ORFL205C_(UL83/pp65) & $\begin{array}{c}65 \mathrm{kDa} \text { lower matrix } \\
\text { phosphoprotein }\end{array}$ \\
\hline 29 & SQYRIQGKLEYRHTW & 15 & ORFL205C_(UL83/pp65) & $\begin{array}{c}65 \mathrm{kDa} \text { lower matrix } \\
\text { phosphoprotein }\end{array}$ \\
\hline 30 & YRHTWDRHDEGAAQG & 15 & ORFL205C_(UL83/pp65) & $\begin{array}{c}65 \mathrm{kDa} \text { lower matrix } \\
\text { phosphoprotein }\end{array}$ \\
\hline 31 & IHNPAVFTWPPWQAG & 15 & ORFL205C_(UL83/pp65) & $\begin{array}{c}65 \mathrm{kDa} \text { lower matrix } \\
\text { phosphoprotein }\end{array}$ \\
\hline 32 & PWQAGILARNLVPMV & 15 & ORFL205C_(UL83/pp65) & $\begin{array}{c}65 \mathrm{kDa} \text { lower matrix } \\
\text { phosphoprotein }\end{array}$ \\
\hline 33 & ATVQGQNLKYQEFFW & 15 & ORFL205C_(UL83/pp65) & $\begin{array}{c}65 \mathrm{kDa} \text { lower matrix } \\
\text { phosphoprotein }\end{array}$ \\
\hline 34 & QNLKYQEFFWDANDI & 15 & ORFL205C_(UL83/pp65) & $\begin{array}{c}65 \mathrm{kDa} \text { lower matrix } \\
\text { phosphoprotein }\end{array}$ \\
\hline 35 & QEFFWDANDIYRIFA & 15 & ORFL205C_(UL83/pp65) & $\begin{array}{c}65 \mathrm{kDa} \text { lower matrix } \\
\text { phosphoprotein }\end{array}$ \\
\hline 36 & ELEGVWQPAAQPKRR & 15 & ORFL205C_(UL83/pp65) & $\begin{array}{c}65 \mathrm{kDa} \text { lower matrix } \\
\text { phosphoprotein }\end{array}$ \\
\hline 37 & IFLEVQAIRETVELR & 15 & ORFL205C_(UL83/pp65) & $\begin{array}{c}65 \mathrm{kDa} \text { lower matrix } \\
\text { phosphoprotein }\end{array}$ \\
\hline 38 & PPWQAGILARNLVPM & 15 & ORFL205C_(UL83/pp65) & $\begin{array}{c}65 \mathrm{kDa} \text { lower matrix } \\
\text { phosphoprotein }\end{array}$ \\
\hline 39 & DVPSGKLFMHVTLGS & 15 & ORFL205C_(UL83/pp65) & $\begin{array}{c}65 \mathrm{kDa} \text { lower matrix } \\
\text { phosphoprotein }\end{array}$ \\
\hline
\end{tabular}




\begin{tabular}{|c|c|c|c|c|}
\hline 40 & KLFMHVTLGSDVEED & 15 & ORFL205C_(UL83/pp65) & $\begin{array}{c}65 \mathrm{kDa} \text { lower matrix } \\
\text { phosphoprotein }\end{array}$ \\
\hline 41 & DVEEDLTMTRNPQPF & 15 & ORFL205C_(UL83/pp65) & $\begin{array}{c}65 \mathrm{kDa} \text { lower matrix } \\
\text { phosphoprotein }\end{array}$ \\
\hline 42 & VAFTSHEHFGLLCPK & 15 & ORFL205C_(UL83/pp65) & $\begin{array}{c}65 \mathrm{kDa} \text { lower matrix } \\
\text { phosphoprotein }\end{array}$ \\
\hline 43 & SEHPTFTSQYRIQGK & 15 & ORFL205C_(UL83/pp65) & $\begin{array}{c}65 \mathrm{kDa} \text { lower matrix } \\
\text { phosphoprotein }\end{array}$ \\
\hline 44 & LEYRHTWDRHDEGAA & 15 & ORFL205C_(UL83/pp65) & $\begin{array}{c}65 \mathrm{kDa} \text { lower matrix } \\
\text { phosphoprotein }\end{array}$ \\
\hline 45 & PLKMLNIPSINVHHY & 15 & ORFL205C_(UL83/pp65) & $\begin{array}{c}65 \mathrm{kDa} \text { lower matrix } \\
\text { phosphoprotein }\end{array}$ \\
\hline 46 & KVYLESFCEDVPSGK & 15 & ORFL205C_(UL83/pp65) & $\begin{array}{c}65 \mathrm{kDa} \text { lower matrix } \\
\text { phosphoprotein }\end{array}$ \\
\hline 47 & TLGSDVEEDLTMTRN & 15 & ORFL205C_(UL83/pp65) & $\begin{array}{c}65 \mathrm{kDa} \text { lower matrix } \\
\text { phosphoprotein }\end{array}$ \\
\hline 48 & ASTSAGRKRKSASSA & 15 & ORFL205C_(UL83/pp65) & $\begin{array}{c}65 \mathrm{kDa} \text { lower matrix } \\
\text { phosphoprotein }\end{array}$ \\
\hline 49 & ACTSGVMTRGRLKAE & 15 & ORFL205C_(UL83/pp65) & $\begin{array}{c}65 \mathrm{kDa} \text { lower matrix } \\
\text { phosphoprotein }\end{array}$ \\
\hline 50 & AGILARNLVPMVATV & 15 & ORFL205C_(UL83/pp65) & $\begin{array}{c}65 \mathrm{kDa} \text { lower matrix } \\
\text { phosphoprotein }\end{array}$ \\
\hline 51 & EPDVYYTSAFVFPTK & 15 & ORFL205C_(UL83/pp65) & $\begin{array}{c}65 \mathrm{kDa} \text { lower matrix } \\
\text { phosphoprotein }\end{array}$ \\
\hline 52 & QVIGDQYVKVYLESF & 15 & ORFL205C_(UL83/pp65) & $\begin{array}{c}65 \mathrm{kDa} \text { lower matrix } \\
\text { phosphoprotein }\end{array}$ \\
\hline
\end{tabular}




\begin{tabular}{|c|c|c|c|c|}
\hline 53 & FFWDANDIYRIFAEL & 15 & ORFL205C_(UL83/pp65) & $\begin{array}{c}65 \mathrm{kDa} \text { lower matrix } \\
\text { phosphoprotein }\end{array}$ \\
\hline 54 & LVSQYTPDSTPCHRG & 15 & ORFL205C_(UL83/pp65) & $\begin{array}{c}65 \mathrm{kDa} \text { lower matrix } \\
\text { phosphoprotein }\end{array}$ \\
\hline 55 & SHIMLDVAFTSHEH & 14 & ORFL205C_(UL83/pp65) & $\begin{array}{c}65 \mathrm{kDa} \text { lower matrix } \\
\text { phosphoprotein }\end{array}$ \\
\hline 56 & DEDSDNEIHNPAVFTW & 16 & ORFL205C_(UL83/pp65) & $\begin{array}{c}65 \mathrm{kDa} \text { lower matrix } \\
\text { phosphoprotein }\end{array}$ \\
\hline 57 & SQYTPDSTPCHRG & 13 & ORFL205C_(UL83/pp65) & $\begin{array}{c}65 \mathrm{kDa} \text { lower matrix } \\
\text { phosphoprotein }\end{array}$ \\
\hline 58 & KPGKISHIMLDVA & 13 & ORFL205C_(UL83/pp65) & $\begin{array}{c}65 \mathrm{kDa} \text { lower matrix } \\
\text { phosphoprotein }\end{array}$ \\
\hline 59 & PTFTSQYRIQGKL & 13 & ORFL205C_(UL83/pp65) & $\begin{array}{c}65 \mathrm{kDa} \text { lower matrix } \\
\text { phosphoprotein }\end{array}$ \\
\hline 60 & DTPVLPHETRLLQTGIHVRV & 20 & ORFL205C_(UL83/pp65) & $\begin{array}{c}65 \mathrm{kDa} \text { lower matrix } \\
\text { phosphoprotein }\end{array}$ \\
\hline 61 & INVHHYPSAAERKHRHLPVA & 20 & ORFL205C_(UL83/pp65) & $\begin{array}{c}65 \mathrm{kDa} \text { lower matrix } \\
\text { phosphoprotein }\end{array}$ \\
\hline 62 & LLQRGPQYSEHPTFT & 15 & ORFL205C_(UL83/pp65) & $\begin{array}{c}65 \mathrm{kDa} \text { lower matrix } \\
\text { phosphoprotein }\end{array}$ \\
\hline 63 & ALFFFDIDLLLQRGPQYSE & 19 & ORFL205C_(UL83/pp65) & $\begin{array}{c}65 \mathrm{kDa} \text { lower matrix } \\
\text { phosphoprotein }\end{array}$ \\
\hline 64 & DQYVKVYLESFCEDVPSGKL & 20 & ORFL205C_(UL83/pp65) & $\begin{array}{c}65 \mathrm{kDa} \text { lower matrix } \\
\text { phosphoprotein }\end{array}$ \\
\hline 65 & $\begin{array}{c}\text { MTRNPQPFMRPHERNGFTV } \\
\mathrm{L}\end{array}$ & 20 & ORFL205C_(UL83/pp65) & $\begin{array}{c}65 \mathrm{kDa} \text { lower matrix } \\
\text { phosphoprotein }\end{array}$ \\
\hline
\end{tabular}




\begin{tabular}{|c|c|c|c|c|}
\hline 66 & MISVLGPISGHVLKAVFSRG & 20 & ORFL205C_(UL83/pp65) & $\begin{array}{c}65 \mathrm{kDa} \text { lower matrix } \\
\text { phosphoprotein }\end{array}$ \\
\hline 67 & $\begin{array}{c}\text { ASGKQMWQARLTVSGLAWT } \\
\mathrm{R}\end{array}$ & 20 & ORFL205C_(UL83/pp65) & $\begin{array}{c}65 \mathrm{kDa} \text { lower matrix } \\
\text { phosphoprotein }\end{array}$ \\
\hline 68 & LPLKMLNIPSINVHHYPSAA & 20 & ORFL205C_(UL83/pp65) & $\begin{array}{c}65 \mathrm{kDa} \text { lower matrix } \\
\text { phosphoprotein }\end{array}$ \\
\hline 69 & PHETRLLQTGIHVRVSQPSL & 20 & ORFL205C_(UL83/pp65) & $\begin{array}{c}65 \mathrm{kDa} \text { lower matrix } \\
\text { phosphoprotein }\end{array}$ \\
\hline 70 & IYVYALPLKMLNIPSINVHH & 20 & ORFL205C_(UL83/pp65) & $\begin{array}{c}65 \mathrm{kDa} \text { lower matrix } \\
\text { phosphoprotein }\end{array}$ \\
\hline 71 & QYDPVAALFFFDIDLLLQRG & 20 & ORFL205C_(UL83/pp65) & $\begin{array}{c}65 \mathrm{kDa} \text { lower matrix } \\
\text { phosphoprotein }\end{array}$ \\
\hline 72 & RQYDPVAALFFFDIDL & 16 & ORFL205C_(UL83/pp65) & $\begin{array}{c}65 \mathrm{kDa} \text { lower matrix } \\
\text { phosphoprotein }\end{array}$ \\
\hline 73 & HETRLLQTGIHVRVS & 15 & ORFL205C_(UL83/pp65) & $\begin{array}{c}65 \mathrm{kDa} \text { lower matrix } \\
\text { phosphoprotein }\end{array}$ \\
\hline 74 & VYALPLKMLNIPSIN & 15 & ORFL205C_(UL83/pp65) & $\begin{array}{c}65 \mathrm{kDa} \text { lower matrix } \\
\text { phosphoprotein }\end{array}$ \\
\hline 75 & VALRHVVCAHELVCS & 15 & ORFL205C_(UL83/pp65) & $\begin{array}{c}65 \mathrm{kDa} \text { lower matrix } \\
\text { phosphoprotein }\end{array}$ \\
\hline 76 & HIMLDVAFTSHEHFG & 15 & ORFL205C_(UL83/pp65) & $\begin{array}{c}65 \mathrm{kDa} \text { lower matrix } \\
\text { phosphoprotein }\end{array}$ \\
\hline 77 & FTSQYRIQGKLEYRH & 15 & ORFL205C_(UL83/pp65) & $\begin{array}{c}65 \mathrm{kDa} \text { lower matrix } \\
\text { phosphoprotein }\end{array}$ \\
\hline 78 & YRIQGKLEYRHTWDR & 15 & ORFL205C_(UL83/pp65) & $\begin{array}{c}65 \mathrm{kDa} \text { lower matrix } \\
\text { phosphoprotein }\end{array}$ \\
\hline
\end{tabular}




\begin{tabular}{|c|c|c|c|c|}
\hline 79 & ARNLVPMVATVQGQN & 15 & ORFL205C_(UL83/pp65) & $\begin{array}{c}65 \mathrm{kDa} \text { lower matrix } \\
\text { phosphoprotein }\end{array}$ \\
\hline 80 & ANDIYRIFAELEGVW & 15 & ORFL205C_(UL83/pp65) & $\begin{array}{c}65 \mathrm{kDa} \text { lower matrix } \\
\text { phosphoprotein }\end{array}$ \\
\hline 81 & TRQQNQWKEPDVYYT & 15 & ORFL205C_(UL83/pp65) & $\begin{array}{c}65 \mathrm{kDa} \text { lower matrix } \\
\text { phosphoprotein }\end{array}$ \\
\hline 82 & TERKTPRVTGGGAMA & 15 & ORFL205C_(UL83/pp65) & $\begin{array}{c}65 \mathrm{kDa} \text { lower matrix } \\
\text { phosphoprotein }\end{array}$ \\
\hline 83 & NLKYQEFFWDANDIY & 15 & ORFL205C_(UL83/pp65) & $\begin{array}{c}65 \mathrm{kDa} \text { lower matrix } \\
\text { phosphoprotein }\end{array}$ \\
\hline 84 & TPRVTGGGAMAGAST & 15 & ORFL205C_(UL83/pp65) & $\begin{array}{c}65 \mathrm{kDa} \text { lower matrix } \\
\text { phosphoprotein }\end{array}$ \\
\hline 85 & DQYVKVYLESFCEDV & 15 & ORFL205C_(UL83/pp65) & HCMVUL83 \\
\hline 86 & GKISHIMLDVAFTSH & 15 & ORFL205C_(UL83/pp65) & HCMVUL83 \\
\hline 87 & EHPTFTSQYRIQGKL & 15 & ORFL205C_(UL83/pp65) & HCMVUL83 \\
\hline 88 & GQNLKYQEFFWDAND & 15 & ORFL205C_(UL83/pp65) & HCMVUL83 \\
\hline 89 & KYQEFFWDANDIYRI & 15 & ORFL205C_(UL83/pp65) & HCMVUL83 \\
\hline 90 & IIKPGKISHIMLDVA & 15 & ORFL205C_(UL83/pp65) & HCMVUL83 \\
\hline 91 & TRATKMQVIGDQYVKVYLES & 20 & ORFL205C_(UL83/pp65) & HCMVUL83 \\
\hline 92 & KLFMHVTLGSDVEEDLTMTR & 20 & ORFL205C_(UL83/pp65) & HCMVUL83 \\
\hline 93 & KPGKISHIMLDVAFTSHEHF & 20 & ORFL205C_(UL83/pp65) & HCMVUL83 \\
\hline 94 & LPVADAVIHASGKQMWQARL & 20 & ORFL205C_(UL83/pp65) & HCMVUL83 \\
\hline 95 & GSDSDEELVTTERKTPRVTG & 20 & ORFL205C_(UL83/pp65) & HCMVUL83 \\
\hline 96 & RHRQDALPGPCIASTPKKHR & 20 & ORFL205C_(UL83/pp65) & HCMVUL83 \\
\hline 97 & YQEFFWDANDIYR & 13 & ORFL205C_(UL83/pp65) & HCMVUL83 \\
\hline 98 & LAWTRQQNQWKEPDV & 15 & ORFL205C_(UL83/pp65) & HCMVUL83 \\
\hline 99 & YQEFFWDANDIYRIF & 15 & ORFL205C_(UL83/pp65) & HCMVUL83 \\
\hline
\end{tabular}




\begin{tabular}{|c|c|c|c|c|}
\hline 100 & EFFWDANDIYRIF & 13 & ORFL205C_(UL83/pp65) & HCMVUL83 \\
\hline 101 & VEEDLTMTRNPQPFM & 15 & ORFL205C_(UL83/pp65) & HCMVUL83 \\
\hline 102 & KPGKISHIMLDVAFTSH & 17 & ORFL205C_(UL83/pp65) & HCMVUL83 \\
\hline 103 & TSQYRIQGKLEYRHT & 15 & ORFL205C_(UL83/pp65) & HCMVUL83 \\
\hline 104 & MSIYVYALPLKMLNI & 15 & ORFL205C_(UL83/pp65) & HCMVUL83 \\
\hline 105 & VYYTSAFVFPTKDVA & 15 & ORFL205C_(UL83/pp65) & HCMVUL83 \\
\hline 106 & LRQYDPVAALFFFDI & 15 & ORFL205C_(UL83/pp65) & HCMVUL83 \\
\hline 107 & GPQYSEHPTFTSQYRI & 16 & ORFL205C_(UL83/pp65) & HCMVUL83 \\
\hline 108 & HPTFTSQYRIQGKLE & 15 & ORFL205C_(UL83/pp65) & HCMVUL83 \\
\hline 109 & TRLLQTGIHVRVSQP & 15 & ORFL205C_(UL83/pp65) & HCMVUL83 \\
\hline 110 & RNGFTVLCPKNMIIK & 15 & ORFL205C_(UL83/pp65) & HCMVUL83 \\
\hline 111 & PISGHVLKAVFSRGD & 15 & ORFL205C_(UL83/pp65) & HCMVUL83 \\
\hline 112 & GIHVRVSQPSLILVS & 15 & ORFL205C_(UL83/pp65) & HCMVUL83 \\
\hline 113 & IHASGKQMWQARLTV & 15 & ORFL205C_(UL83/pp65) & HCMVUL83 \\
\hline 114 & GKQMWQARLTVSGLA & 15 & ORFL205C_(UL83/pp65) & HCMVUL83 \\
\hline 115 & ENTRATKMQVIGDQY & 15 & ORFL205C_(UL83/pp65) & HCMVUL83 \\
\hline 116 & ATKMQVIGDQYVKVY & 15 & ORFL205C_(UL83/pp65) & HCMVUL83 \\
\hline 117 & RPHERNGFTVLCPKN & 15 & ORFL205C_(UL83/pp65) & HCMVUL83 \\
\hline 118 & AQGDDDVWTSGSDSD & 15 & ORFL205C_(UL83/pp65) & HCMVUL83 \\
\hline 119 & SSATACTSGVMTRGR & 15 & ORFL205C_(UL83/pp65) & HCMVUL83 \\
\hline 120 & YRIFAELEGVWQPAA & 15 & ORFL205C_(UL83/pp65) & HCMVUL83 \\
\hline 121 & AELEGVWQPAAQPKR & 15 & ORFL205C_(UL83/pp65) & HCMVUL83 \\
\hline 122 & AVFSRGDTPVLPHET & 15 & ORFL205C_(UL83/pp65) & $\begin{array}{l}\text { phosphorylated matrix protein } \\
\qquad(\mathrm{pp} 65)\end{array}$ \\
\hline 123 & ALPLKMLNIPSINVH & 15 & ORFL205C_(UL83/pp65) & pp65 \\
\hline 124 & HVLKAVFSRGDTPVL & 15 & ORFL205C_(UL83/pp65) & pp65 \\
\hline 125 & AHELVCSMENTRATKMQVIG & 20 & ORFL205C_(UL83/pp65) & tegument protein pp65 \\
\hline
\end{tabular}




\begin{tabular}{|c|c|c|c|c|}
\hline 126 & FCEDVPSGKLFMHVTLGSDV & 20 & ORFL205C_(UL83/pp65) & tegument protein pp65 \\
\hline 127 & TLGSDVEEDLTMTRNPQPF & 19 & ORFL205C_(UL83/pp65) & tegument protein pp65 \\
\hline 128 & LLQTGIHVRVSQPSLILV & 18 & ORFL205C_(UL83/pp65) & tegument protein pp65 \\
\hline 129 & SICPSQEPMSIYVYA & 15 & ORFL205C_(UL83/pp65) & tegument protein pp65 \\
\hline 130 & SQEPMSIYVYALPLK & 15 & ORFL205C_(UL83/pp65) & tegument protein pp65 \\
\hline 131 & LNIPSINVHHYPSAA & 15 & ORFL205C_(UL83/pp65) & tegument protein pp65 \\
\hline 132 & HDVSKGDDNKLGGALQAKA & 19 & ORFL264C_(UL123) IE1 & $\begin{array}{c}55 \mathrm{kDa} \text { immediate-early } \\
\text { protein } 1\end{array}$ \\
\hline 133 & ALQAKARDKKDELRRKMMY & 19 & ORFL264C_(UL123) IE1 & $\begin{array}{c}55 \mathrm{kDa} \text { immediate-early } \\
\text { protein } 1\end{array}$ \\
\hline 134 & KEHMLKKYTQTEEKF & 15 & ORFL264C_(UL123) IE1 & $\begin{array}{c}55 \mathrm{kDa} \text { immediate-early } \\
\text { protein } 1\end{array}$ \\
\hline 135 & QTEEKFTGAFNMMGGCLQN & 19 & ORFL264C_(UL123) IE1 & $\begin{array}{c}55 \mathrm{kDa} \text { immediate-early } \\
\text { protein } 1\end{array}$ \\
\hline 136 & MGGCLQNALDILDKVHEPFE & 20 & ORFL264C_(UL123) IE1 & $\begin{array}{c}55 \mathrm{kDa} \text { immediate-early } \\
\text { protein } 1\end{array}$ \\
\hline 137 & AIVAYTLATAGVSSSDSLV & 19 & ORFL264C_(UL123) IE1 & $\begin{array}{c}55 \mathrm{kDa} \text { immediate-early } \\
\text { protein } 1\end{array}$ \\
\hline 138 & TMQSMYENYIVPEDKREMW & 19 & ORFL264C_(UL123) IE1 & $\begin{array}{c}55 \mathrm{kDa} \text { immediate-early } \\
\text { protein } 1\end{array}$ \\
\hline 139 & RRKMMYMCYRNIEFFTKNS & 19 & ORFL264C_(UL123) IE1 & $\begin{array}{c}55 \mathrm{kDa} \text { immediate-early } \\
\text { protein } 1\end{array}$ \\
\hline 140 & FFTKNSAFPKTTNGCSQAM & 19 & ORFL264C_(UL123) IE1 & $\begin{array}{c}55 \mathrm{kDa} \text { immediate-early } \\
\text { protein } 1\end{array}$ \\
\hline 141 & CVETMCNEYKVTSDACMMT & 19 & ORFL264C_(UL123) IE1 & $\begin{array}{c}55 \mathrm{kDa} \text { immediate-early } \\
\text { protein } 1\end{array}$ \\
\hline
\end{tabular}




\begin{tabular}{|c|c|c|c|c|}
\hline 142 & DACMMTMYGGASLLSEFCR & 19 & ORFL264C_(UL123) IE1 & $\begin{array}{c}55 \mathrm{kDa} \text { immediate-early } \\
\text { protein } 1\end{array}$ \\
\hline 143 & NYIVPEDKREMWMACIKELH & 20 & ORFL264C_(UL123) IE1 & $\begin{array}{c}55 \mathrm{kDa} \text { immediate-early } \\
\text { protein } 1\end{array}$ \\
\hline 144 & VRHRIKEHMLKKYTQTEEKF & 20 & ORFL264C_(UL123) IE1 & $\begin{array}{c}55 \mathrm{kDa} \text { immediate-early } \\
\text { protein } 1\end{array}$ \\
\hline 145 & VRVDMVRHRIKEHML & 15 & ORFL264C_(UL123) IE1 & $\begin{array}{c}55 \mathrm{kDa} \text { immediate-early } \\
\text { protein } 1\end{array}$ \\
\hline 146 & VKQIKVRVDMVRHRI & 15 & ORFL264C_(UL123) IE1 & $\begin{array}{c}55 \mathrm{kDa} \text { immediate-early } \\
\text { protein } 1\end{array}$ \\
\hline 147 & VRHRIKEHMLKKYTQ & 15 & ORFL264C_(UL123) IE1 & $\begin{array}{c}55 \mathrm{kDa} \text { immediate-early } \\
\text { protein } 1\end{array}$ \\
\hline 148 & EQSDEEEEEGAQEER & 15 & ORFL264C_(UL123) IE1 & $\begin{array}{c}55 \mathrm{kDa} \text { immediate-early } \\
\text { protein } 1\end{array}$ \\
\hline 149 & VKSEPVSEIEEVAPE & 15 & ORFL264C_(UL123) IE1 & $\begin{array}{c}55 \mathrm{kDa} \text { immediate-early } \\
\text { protein } 1\end{array}$ \\
\hline 150 & PVSEIEEVAPEEEED & 15 & ORFL264C_(UL123) IE1 & $\begin{array}{c}55 \mathrm{kDa} \text { immediate-early } \\
\text { protein } 1\end{array}$ \\
\hline 151 & LQNALDILDKVHEPF & 15 & ORFL264C_(UL123) IE1 & $\begin{array}{c}55 \mathrm{kDa} \text { immediate-early } \\
\text { protein } 1\end{array}$ \\
\hline 152 & EDKREMWMACIKELH & 15 & ORFL264C_(UL123) IE1 & $\begin{array}{c}55 \mathrm{kDa} \text { immediate-early } \\
\text { protein } 1\end{array}$ \\
\hline 153 & THIDHIFMDILTTCV & 15 & ORFL264C_(UL123) IE1 & $\begin{array}{c}55 \mathrm{kDa} \text { immediate-early } \\
\text { protein } 1\end{array}$ \\
\hline 154 & VLEETSVMLAKRPLI & 15 & ORFL264C_(UL123) IE1 & $\begin{array}{c}55 \mathrm{kDa} \text { immediate-early } \\
\text { protein } 1\end{array}$ \\
\hline
\end{tabular}




\begin{tabular}{|c|c|c|c|c|}
\hline 155 & TKPEVISVMKRRIEE & 15 & ORFL264C_(UL123) IE1 & $\begin{array}{c}55 \mathrm{kDa} \text { immediate-early } \\
\text { protein } 1\end{array}$ \\
\hline 156 & RRIEEICMKVFAQYI & 15 & ORFL264C_(UL123) IE1 & $\begin{array}{c}55 \mathrm{kDa} \text { immediate-early } \\
\text { protein } 1\end{array}$ \\
\hline 157 & NIEFFTKNSAFPKTT & 15 & ORFL264C_(UL123) IE1 & regulatory protein IE1 \\
\hline 158 & LTHIDHIFMDILTTCVETM & 19 & ORFL264C_(UL123) IE1 & regulatory protein IE1 \\
\hline 159 & AIVAYTLATAGASSSDSLV & 19 & ORFL264C_(UL123) IE1 & UL123; IE1 \\
\hline 160 & VRVDMVRHRIKEHMLKKYTQ & 20 & ORFL264C_(UL123) IE1 & UL123; IE1 \\
\hline 161 & DKREMWMACIKELH & 14 & ORFL264C_(UL123) IE1 & UL123; IE1 \\
\hline 162 & $\begin{array}{c}\text { QSMYENYIVPEDKREMWMA } \\
\text { C }\end{array}$ & 20 & ORFL264C_(UL123) IE1 & UL123; IE1 \\
\hline 163 & TRRGRVKIDEVSRMF & 15 & ORFL265C_(UL122) IE2 & $\begin{array}{c}45 \mathrm{kDa} \text { immediate-early } \\
\text { protein } 2\end{array}$ \\
\hline 164 & GDILAQAVNHAGIDS & 15 & ORFL265C_(UL122) IE2 & $\begin{array}{c}45 \mathrm{kDa} \text { immediate-early } \\
\text { protein } 2\end{array}$ \\
\hline 165 & KTTRPFKVIIKPPVP & 15 & ORFL265C_(UL122) IE2 & $\begin{array}{c}45 \mathrm{kDa} \text { immediate-early } \\
\text { protein } 2\end{array}$ \\
\hline 166 & FKVIIKPPVPPAPIM & 15 & ORFL265C_(UL122) IE2 & $\begin{array}{c}45 \mathrm{kDa} \text { immediate-early } \\
\text { protein } 2\end{array}$ \\
\hline 167 & PEPDFTIQYRNKIID & 15 & ORFL265C_(UL122) IE2 & $\begin{array}{c}45 \mathrm{kDa} \text { immediate-early } \\
\text { protein } 2\end{array}$ \\
\hline 168 & PFTIPSMHQVLDEAI & 15 & ORFL265C_(UL122) IE2 & $\begin{array}{c}45 \mathrm{kDa} \text { immediate-early } \\
\text { protein } 2\end{array}$ \\
\hline 169 & LMQKFPKQVMVRIFS & 15 & ORFL265C_(UL122) IE2 & $\begin{array}{c}45 \mathrm{kDa} \text { immediate-early } \\
\text { protein } 2\end{array}$ \\
\hline 170 & VRIFSTNQGGFMLPI & 15 & ORFL265C_(UL122) IE2 & $\begin{array}{c}45 \mathrm{kDa} \text { immediate-early } \\
\text { protein } 2\end{array}$ \\
\hline
\end{tabular}




\begin{tabular}{|c|c|c|c|c|}
\hline 171 & PEDLDTLSLAIEAAI & 15 & ORFL265C_(UL122) IE2 & $\begin{array}{c}45 \mathrm{kDa} \text { immediate-early } \\
\text { protein } 2\end{array}$ \\
\hline 172 & TLSLAIEAAIQDLRN & 15 & ORFL265C_(UL122) IE2 & $\begin{array}{c}45 \mathrm{kDa} \text { immediate-early } \\
\text { protein } 2\end{array}$ \\
\hline 173 & SMHQVLDEAIKACKT & 15 & ORFL265C_(UL122) IE2 & $\begin{array}{c}45 \mathrm{kDa} \text { immediate-early } \\
\text { protein } 2\end{array}$ \\
\hline 174 & KGIQIIYTRNHEVKS & 15 & ORFL265C_(UL122) IE2 & $\begin{array}{c}45 \mathrm{kDa} \text { immediate-early } \\
\text { protein } 2\end{array}$ \\
\hline 175 & ALSTPFLMEHTMPVT & 15 & ORFL265C_(UL122) IE2 & $\begin{array}{c}45 \mathrm{kDa} \text { immediate-early } \\
\text { protein } 2\end{array}$ \\
\hline 176 & FLMEHTMPVTHPPEV & 15 & ORFL265C_(UL122) IE2 & $\begin{array}{c}45 \mathrm{kDa} \text { immediate-early } \\
\text { protein } 2\end{array}$ \\
\hline 177 & PYAVAFQPLLAYAY & 14 & UL57 & $\begin{array}{c}\text { single-stranded DNA-binding } \\
\text { protein }\end{array}$ \\
\hline 178 & KTQLNRHSYLKDSDFLDAA & 19 & UL75 & envelope glycoprotein $\mathrm{H}$ \\
\hline 179 & RQTEKHELLVLVKKAQLNRH & 20 & UL75 & Glycoprotein H precursor \\
\hline 180 & LDPHAFHLLLNTYGRPIR & 18 & UL75 & Glycoprotein H precursor \\
\hline 181 & KAQLNRHSYLKDSDFLDAA & 19 & UL75 & Glycoprotein H precursor \\
\hline 182 & DVLKSGRCQMLDRRTVEMA & 19 & UL75 & Glycoprotein H precursor \\
\hline 183 & LDKAFHLLLNTYGRPIR & 17 & UL75 & Glycoprotein H precursor \\
\hline 184 & KDQLNRHSYLKDPDFLDAA & 19 & UL75 & Glycoprotein H precursor \\
\hline 185 & SYLKDSDFLDAAL & 13 & UL75 & HCMVUL75 \\
\hline 186 & RRIPHFYRVRREVPRTVNE & 19 & UL86 & Major capsid protein \\
\hline 187 & MDVNYFKIPNNPRGRASCM & 19 & UL86 & Major capsid protein \\
\hline
\end{tabular}


806 Table 3: Demographic characteristics of HCMV (+/-) subjects analyzed in

807 screening and validation studies.

808

\begin{tabular}{|c|c|c|c|}
\hline \multirow[b]{2}{*}{ Characteristics } & Screening cohort & \multicolumn{2}{|c|}{ Validation cohort } \\
\hline & HCMV+ & HCMV+ & HCMV- \\
\hline Total participants enrolled, $n$ & 19 & 10 & 10811 \\
\hline Males/females & $10 / 9$ & $3 / 7$ & $3 / 7_{812}$ \\
\hline Median age (range) & $65(28-80)$ & $35.5(22-55)$ & $28.5(19-42)$ \\
\hline Caucasian, \% (n) & $68(13)$ & $40(4)$ & $40(4)_{14}$ \\
\hline Asian, \% (n) & $16(3)$ & $10(1)$ & $20(2)_{15}$ \\
\hline African American, \% (n) & $5(1)$ & $10(1)$ & $10(1817$ \\
\hline More than one race, $\%(n)$ & $0(0)$ & $30(3)$ & $30(3)^{100}$ \\
\hline Unknown, \% (n) & $10(2)$ & $10(1)$ & $0(0)$ \\
\hline
\end{tabular}

